\title{
Economic Values of Protected Areas
}

\section{Guidelines for Protected Area Managers}

Task Force on Economic Benefits of Protected Areas of the World Commission on Protected Areas (WCPA) of IUCN in collaboration with the Economics Service Unit of IUCN

Adrian Phillips, Series Editor

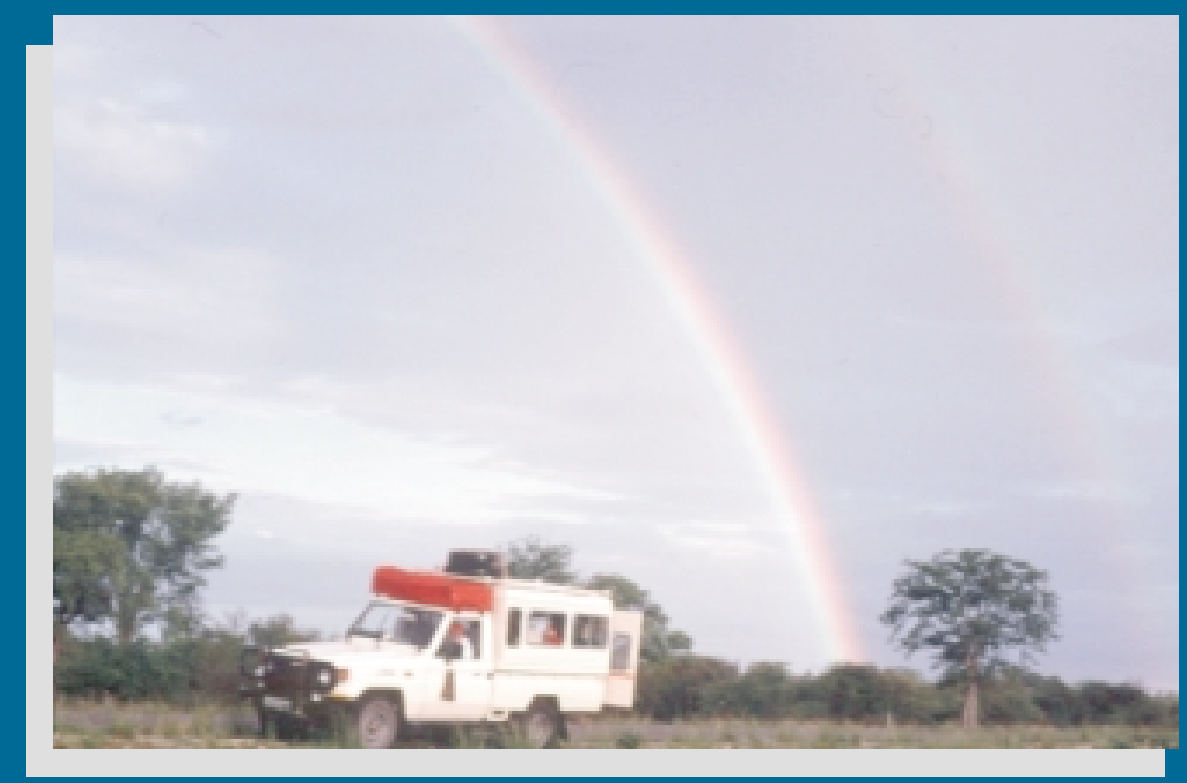

Best Practice Protected Area Guidelines Series No. 2 


\section{Economic Values of Protected Areas}

Guidelines for Protected Area Managers 


\section{IUCN The World Conservation Union}

Founded in 1948, The World Conservation Union brings together States, government agencies and a diverse range of non-governmental organizations in a unique world partnership: over 900 members in all, spread across some 138 countries.

As a Union, IUCN seeks to influence, encourage and assist societies throughout the world to conserve the integrity and diversity of nature and to ensure that any use of natural resources is equitable and ecologically sustainable. A central secretariat coordinates the IUCN Programme and serves the Union membership, representing their views on the world stage and providing them with the strategies, services, scientific knowledge and technical support they need to achieve their goals. Through its six Commissions, IUCN draws together over 10,000 expert volunteers in project teams and action groups, focusing in particular on species and biodiversity conservation and the management of habitats and natural resources. The Union has helped many countries to prepare National Conservation Strategies, and demonstrates the application of its knowledge through the field projects it supervises. Operations are increasingly decentralized and are carried forward by an expanding network of regional and country offices, located principally in developing countries.

The World Conservation Union builds on the strengths of its members, networks and partners to enhance their capacity and to support global alliances to safeguard natural resources at local, regional and global levels.

\section{Cardiff University}

The Department of City and Regional Planning, Cardiff University is pleased to be a partner in the production of this important series of guidelines for protected area planning and management. The Department, through its Environmental Planning Research Unit, is actively involved in protected areas research; runs specialised courses on planning and environmental policy; and has a large Graduate School offering opportunities for persons interested in pursuing research for a $\mathrm{PhD}$ or as part of wider career development. If you are interested in learning more about the Department, its research capabilities and courses please write to us at the address given below.

Professor Jeremy Alden BSc M.Ltt PHD MRTPI

Head of Department

Department of City and Regional Planning

Cardiff University

PO BOX 906

Cardiff

CFl 3YN

Tel: $\quad+441222874308$

Fax: + 441222874845

Email: AldenJD@cf.ac.uk 


\section{Economic Values of Protected Areas}

\section{Guidelines for Protected Area Managers}

Task Force on Economic Benefits of Protected Areas of the World Commission on Protected Areas (WCPA) of IUCN, in collaboration with the Economics Service Unit of IUCN

Adrian Phillips, Series Editor

World Commission on Protected Areas (WCPA)

Best Practice Protected Area Guidelines Series No. 2

IUCN The World Conservation Union 1998 
The designation of geographical entities in this book, and the presentation of the material, do not imply the expression of any opinion whatsoever on the part of IUCN or Cardiff University concerning the legal status of any country, territory, or area, or of its authorities, or concerning the delimitation of its frontiers or boundaries. Furthermore, the views expressed in this publication do not necessarily reflect those of IUCN or Cardiff University.

This publication has been made possible to a large part by funding from Cardiff University, Environment Australia and IUCN.

Published by: $\quad$ IUCN, Gland, Switzerland, and Cambridge, UK.

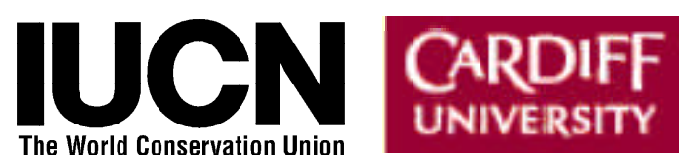

Copyright: $\quad$ C 1998 International Union for the Conservation of Nature and Natural Resources

Reproduction of this publication for educational or other non-commercial purposes is authorized without prior written permission from the copyright holder provided the source is fully acknowledged.

Reproduction of this publication for resale or other commercial purposes is prohibited without prior written permission of the copyright holders.

Citation: $\quad$ Task Force on Economic Benefits of Protected Areas of the World Commission on Protected Areas (WCPA) of IUCN, in collaboration with the Economics Service Unit of IUCN (1998). Economic Values of Protected Areas: Guidelines for Protected Area Managers. IUCN, Gland, Switzerland and Cambridge, UK. xii+52pp.

ISBN: $\quad$ 2-8317-0461-8

Cover design by: IUCN Publications Services Unit

Cover photos: @ Tourist Landrover Etosha National Park, Namibia, Joshua Schachter

Layout by: $\quad$ IUCN Publications Services Unit

Produced by: IUCN Publications Services Unit, Cambridge, UK

Printed by: $\quad$ Page Bros (Norwich) Ltd, UK

Available from: IUCN Publications Services Unit

219c Huntingdon Road, Cambridge CB3 ODL,

United Kingdom

Tel: ++44 1223277894

Fax: ++44 1223277175

E-mail: info@books.iucn.org

www: http://www.iucn.org

Also available at http://economics.iucn.org/valuationparks.htm

A catalogue of IUCN publications is also available 


\section{Table of Contents}

Editorial preface $\ldots \ldots \ldots \ldots \ldots \ldots \ldots \ldots \ldots \ldots \ldots \ldots \ldots \ldots \ldots \ldots \ldots \ldots$

Acknowledgements $\ldots \ldots \ldots \ldots \ldots \ldots \ldots \ldots \ldots \ldots \ldots \ldots \ldots \ldots \ldots \ldots$ viii

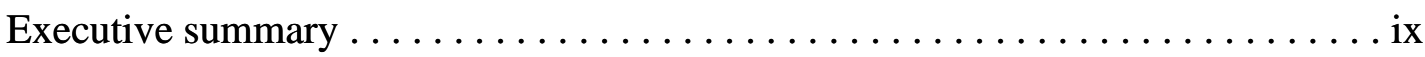

Introduction $\ldots \ldots \ldots \ldots \ldots \ldots \ldots \ldots \ldots \ldots \ldots \ldots \ldots \ldots \ldots \ldots \ldots \ldots$

\section{Testimonials}

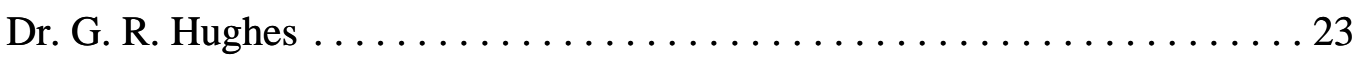

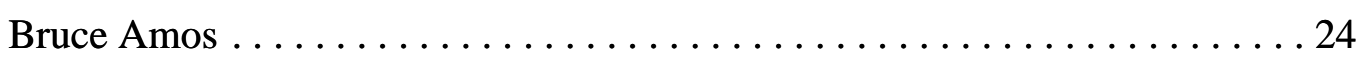

PART I . . . . . . . . . . . . . . . . . . . . .

1. A new vision for protected areas. ..................... 3

1.1 The global mandate for protected areas. . . . . . . . . . . 3

1.2 The need for innovative approaches $\ldots \ldots \ldots \ldots \ldots \ldots \ldots$

1.3 The 'client' approach $\ldots \ldots \ldots \ldots \ldots \ldots \ldots \ldots \ldots \ldots \ldots$

2. Economic values of protected areas $\ldots \ldots \ldots \ldots \ldots \ldots \ldots \ldots \ldots \ldots$

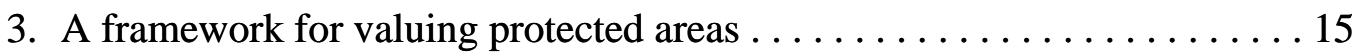

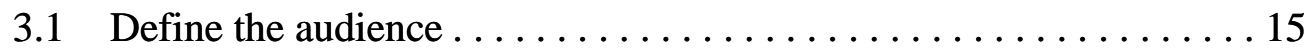

3.2 Determine the scope in terms of the time, data, resources and

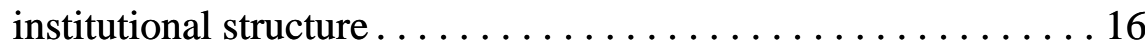

3.3 Choose the analytical technique $\ldots \ldots \ldots \ldots \ldots \ldots \ldots \ldots \ldots$

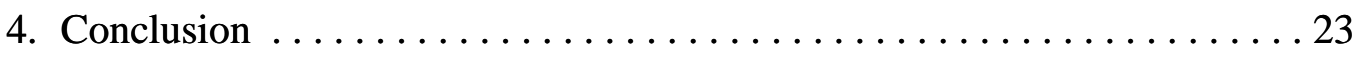

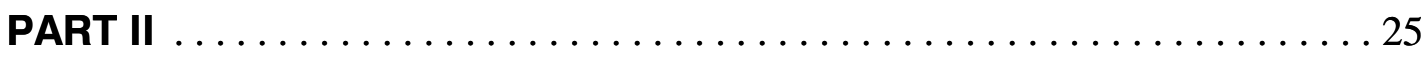

1. Valuation study examples ........................ 27

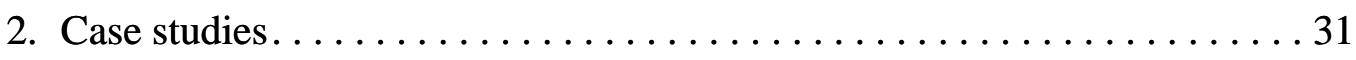

2.1 Opportunity costs of protected areas in Uganda . . . . . . . . . 31

2.2 Contingent valuation and costless choice methods in Kenya . . . . . 34

2.3 Loss of productivity and contingent valuation in Madagascar . . . . . 34

2.4 Stakeholder identification for Indonesian coral reefs . . . . . . . . . 35

2.5 The value of forest reconstruction to the Croatian tourism

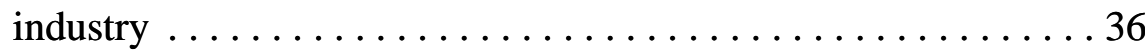


$2.6 \quad$ Willingness to pay for a protected area in India $\ldots \ldots \ldots \ldots 38$

2.7 Opportunity costs of alternative forestry practices in Nepal . . . . 39

2.8 Using a valuation study to capture revenues in South Africa . . . . 40

$2.9 \quad$ Benefit cost analysis in South Africa. . . . . . . . . . . . . . 41

2.10 The economic contribution of key conservation areas in South

Africa ........................... 42

2.11 Total economic value in Kenya ................ 43

2.12 Financial benefits to a local economy in Australia . . . . . . . . . 44

2.13 Financial benefits to a regional economy in Australia . . . . . . . 44

2.14 The effect of environmental quality on consumer demand in

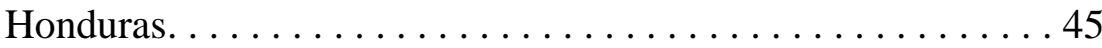

2.15 Local and national financial benefits from protected areas in

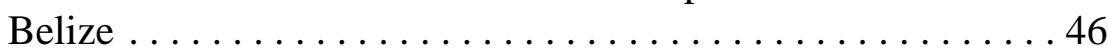

2.16 The opportunity cost of a Fijian mangrove $\ldots \ldots \ldots \ldots \ldots 7$

Bibliography. ................................ 49

Boxes and tables

Box 1. Six categories of protected areas $\ldots \ldots \ldots \ldots \ldots \ldots \ldots \ldots$

Box 2. Total economic value. . . . . . . . . . . . . . . . . . . . . . 11

Box 3. Economic valuation and financial analysis . . . . . . . . 12

Box 4. Total economic values of protected areas . . . . . . . . . 13

Box 5. Analytical matrix for protected areas . . . . . . . . . . 15

Box 6. Markets and some means of capturing direct use values. . . . . 18

Box 7. The Money Generation Model. . . . . . . . . . . . . . . 20

Box 8. Willingness to pay and willingness to accept $\ldots \ldots \ldots 21$

Table 1 . Summary of the case studies . . . . . . . . . . . . . 28 


\section{Editorial preface}

This is the second in a new series of Best Practice Guidelines produced by the IUCN World Commission on Protected Areas (WCPA) in partnership with the Environmental Planning Research Unit, Department of City and Regional Planning, Cardiff University, Wales, UK.

WCPA, which is an integral part of IUCN - The World Conservation Union - is a world-wide network of some 1,300 protected area experts. Its members work in a volunteer capacity to raise the standard of protected areas planning and management. The Department of City and Regional Planning at Cardiff University is the UK's leading school of planning. It has a strong international reputation and a high profile in research and teaching related to environmental topics. Together the two bodies are working to produce and distribute a series of world best practice guidelines. There will be two publications a year, prepared through experts drawn from WCPA's network, initially over a three year period. Drafting of each individual guideline publication will normally be led by a main author, usually assisted by a task force and subject to peer review with WCPA. The first in the series dealt with National System Planning for Protected Areas. The series will address other key issues facing protected areas around the world such as marine protected areas, tourism and protected areas, financing of protected areas and training.

The guidelines series is intended to be used by all those concerned with the policy and practice of protected areas, not only the practitioners but also decision-makers at the various levels of government, others such as non-governmental organisations, academics and students and international funding agencies. Through the publication and distribution of these guidelines, WCPA and Cardiff University hope to improve understanding of the needs of protected area management and the standards of management on the ground.

As series editor, I welcome feedback from readers.

Adrian Phillips

Chair WCPA and Professor of Countryside and Environmental Planning at the Department of City and Regional Planning, Cardiff University, Wales, UK 


\section{Acknowledgements}

This guide is a publication of IUCN - The World Conservation Union. It has been prepared jointly by the Task Force on Economic Benefits of Protected Areas, a part of the World Commission on Protected Areas (WCPA) and the IUCN Economics Service Unit.

\section{Task force members}

Mr Lee Thomas (Convenor), Dr John Dixon, Dr George Hughes, Mr Effendy Sumardja, Mr Graeme Kelleher, Mr David Sheppard, Dr Michael Green, Mr Pedro Rosabal and Dr Frank Vorhies.

\section{IUCN Economics Service Unit}

Dr Frank Vorhies and Ms Andrea Bagri

The clearance process for the guide has included a review of the text by all members of the Economic Benefits of Protected Areas Task Force, Jeff McNeely, Chief Scientist and other selected IUCN professional staff, and final approval of the IUCN Director General. This process ensures that the document incorporates comments by members of the organisation, but views expressed in this publication do not necessarily reflect those of IUCN. Although IUCN assumes no responsibility for the content of the case studies, any queries can be directed to <indaba.iucn.org>. The publication is also available at: <http://economics.iucn.org/valuationparks.htm>.

The Economic Benefits Task Force wishes to acknowledge the generous support of the IUCN Economics Service Unit and Environment Australia which have assisted in funding the publication of these Guidelines. This funding has contributed to a significantly increased print run and wider distribution of these Guidelines than would otherwise have been possible.

The Task Force and ESU would like to thank Mr Francis Grey, Ms Jill Blockhus and Mr Sebastian Winkler for their contributions to the Guidelines. Comments and assistance from Mr Geert Creemers, Mr Jerry Harrison, Mr Dick Stanley, Dr Luc Peron and Dr Ken Hornback are also acknowledged. 


\section{Executive summary}

Protected areas contain some of the world's most beautiful scenery and outstanding natural and cultural landscapes. These feature wildernesses, mountains and volcanoes, rain forests, untouched crystal-clear marine waters, white sandy beaches and unique cultural sites - to mention but a few.

The natural and near-natural features of protected areas offer attractions which in many countries have become the cornerstone of tourism and recreation. However promoting tourism for the economy is not the primary role of most protected areas. Their primary role is the conservation of species biodiversity, and provision of a rich natural resource which permits scientists, educators and the community at large to meet their various needs. Generally speaking, however, the market alone does not support a system of protected areas - hence society, through its various levels of government, must provide environmental protection as a public service in the same manner that it provides health, education, defence and legal systems. Failure to provide these public services impoverishes the quality of life for individuals and indeed for entire nations.

The debate over environmental protection is often about the balance between leaving areas in their natural or near-natural state, and developing and exploiting them. This choice is fraught with tension - for example should a forest be left uncleared, or logged and converted to agriculture? Should wetlands and mangroves be left in their natural state or cleared and developed?

These Guidelines are intended to help answer such questions. Part I gives an overview of how the economic values of protected areas can be assessed, provide new insights and inform the debate. The case studies in Part II identify those sites where protecting the environment has made a significant contribution to the economy increasing national wealth, national incomes and levels of national economic output.

Public policy has a broad focus on the welfare of the community, and much work has been done by economists systematising the evaluation of welfare benefits from protected areas. The current political process largely focuses, however, on the economy and monetary returns. It is hoped that the awareness developed through these Guidelines can help to place environmental protection issues nearer the centre of the economic policy argument.

The Guidelines reveal that protected areas are often significant revenue-earning entities and can make an important contribution to local economies. For instance recent studies indicate that Canada is expected to create \$C6.5 billion dollars in annual Gross Domestic Product from the expenditure of participants in wildlife-related activities; this sustains 159,000 jobs and creates $\$ C 2.5$ billion in tax revenue each year. Australia receives over \$A2 billion in expenditure from eight national parks - at a direct cost to Governments of some \$A60 million. In Costa Rica, about \$US12 million is spent 
annually to maintain the national parks but foreign exchange generated in 1991 was more than \$US330 million with 500,000 overseas visitors; park-generated tourism is the second largest industry in the country.

Numerous other examples abound. In Tanzania, poaching and uncontrolled hunting of elephants to the south-east of Tarangire National Park led to an increase in woody plants within the park, causing in turn an increase in tsetse flies and hence livestock losses; conservation of elephants would have enhanced the productivity of the livestock industry. Zaire (now Democratic Republic of Congo) receives $75 \%$ of animal protein from wild sources; $40 \%$ of the diet in Botswana comes from animal protein produced by wild sources; firewood and dung provide $90 \%$ of the energy needs in Tanzania, Nepal and Malawi, and exceed $80 \%$ in other countries. In Australia, water production in the Upper Thompson dam in Victoria was found to be more valuable than timber production from the same land. Tourism and fishing are more economically valuable than logging in the Philippines. Fijian mangroves are more valuable for firewood collection, fishing and sewage disposal than when cleared as agricultural land. The destruction of US coastal estuaries between 1954 and 1978 cost the US economy \$200 million in fish production on an annual basis. In Italy, the Abruzzo National Park has been so popular that it has regenerated the economy of a poor area that previously suffered from severe depopulation. In each of these cases, the economy is demonstrably receiving a boost from the existence of protected areas, wildlife and natural and near-natural landscapes.

There is a clear message from the above that investment in protected areas can provide a significant benefit to national and local economies. Far from being locked up and lost to local users, these areas represent an opportunity for sustainable industries and for the generation of financial returns. The concept of total economic value (TEV) identifies the goods and services or "products" protected areas offer and which are suitable for capturing revenues for the protected area. With proper management, the "product" on offer can be sold over and over again without diminishing its value and revenues can be used to maintain the protected area. Unlike extractive industries, the string of returns can be maintained over a long period for the benefit of a wide range of users and stakeholders. Managers need to prepare business plans for parks and reserves so as to assess and capture these potential benefits, and thus ensure the long-term financial sustainability of protected areas in their care.

Case studies reviewed in this report show that the different approaches to valuation can lead to inconsistent reporting of outcomes. The Guidelines therefore recommend a standardised valuation methodology, based on the concept of TEV, which is described in the text. The methodology provides sound guidance for those unfamiliar with measuring costs and benefits. The adoption of a standardised approach will reduce the incidence of impacts remaining unvalued and unappreciated. Measuring the benefits of protected areas in a standard way also enables comparisons and aggregations to be made of studies in different parts of the world. 


\section{Introduction}

The aims of these Guidelines are:

- to introduce protected area managers to the concept and tools of economic valuation, and

- to demonstrate the potential uses of economic valuation for protected area financing and management.

Economic valuation can be useful for protected area managers since it can help:

- support requests for funding from traditional sources,

- identify additional sources of finance,

- expose marginalised stakeholders who may impose threats to protected areas,

- indicate ways of capturing values of beneficiaries, and

- guide management practices.

An effective valuation study should be conducted by a professional economist who is servicing the needs of the protected area manager. It is the protected area manager's task to work with the economist to establish the end use of the study, and the framework for the analysis. This guide is meant to help the manager ask the right questions of the economist.

While these Guidelines should equip protected area managers with the knowledge and information needed to commission a valuation study by an economist it will not prepare either of them to undertake a study independently. A successful valuation study needs the strong guidance and concrete objectives, which the protected area manager should provide, as well as the sound understanding and knowledge of valuation tools and frameworks, which the professional economist can provide.

These Guidelines for protected area managers are in two parts:

Part I provides core information about economic valuation, and

Part II summarises a series of case studies.

Part I outlines the concepts, methodologies and language of economic valuation and is intended to be read in its entirety. The text explains the mandate for protected areas, introduces a client approach to managing protected areas, and establishes the need for valuation against a background of shrinking traditional funding sources. Part I also establishes a three-step framework for valuing protected areas, demonstrates the 
valuation process through a worked example, and draws some important conclusions for protected area managers. Part II summarises a number of case studies with the aim of introducing the manager to valuation in practice. These summaries can be read selectively. The collection as a whole provides examples of the array of situations and levels at which valuation studies can be and have been undertaken.

These are guidelines for protected area managers; they are complemented by

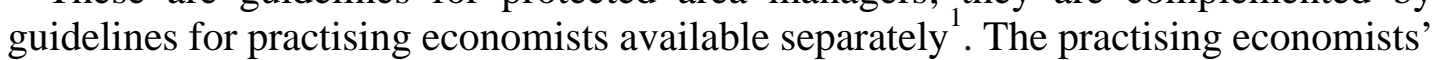
guide will provide background information on how valuation tools can be and have been used for protected areas and supply a tool kit of references and case studies to demonstrate 'best practice'. The two guides are intended to provide protected area managers and their economists with the common framework and language needed to work together effectively and efficiently. An effective valuation study is one which results in policy and management outcomes which improve the long term viability of the protected area; an efficient one achieves these policy and management outcomes in the most expedient and least costly way.

The hope of IUCN's World Commission on Protected Areas (WCPA) is that this guide will become a dynamic document which will be progressively refined as more protected area managers use valuation tools to aid management and finance decisions. The electronic version of the document (http://economics.iucn/valuationparks) will be updated as appropriate, as the ideas presented in this guide are shared and practised in the field. As this experience accumulates, it is hoped that the hard copy version will also be revisited and new cases included. To achieve such dynamism, we look to users of this guide to share experiences by contributing case studies to the Commission <economics@indaba.iucn.org>. These studies can be made available on the Internet, thereby initiating the exchange of experience in the economic valuation of protected areas.

Lee Thomas

Director of Area Management and Planning

Biodiversity Group of Environment Australia and Convenor of the WCPA Economic Benefits Task Force.

\footnotetext{
${ }^{1}$ The economists' guidelines are being prepared and are expected to be completed by the end of 1998 .
} 


\section{PART I}

This part of the Guidelines provides background information about economic valuation techniques, examples of the various values which protected areas may have, and an explanation of how protected area managers can use valuation methodologies as input into financial and management decision-making processes. This section emphasises the need to define the purpose of the valuation study before embarking on the study both in order to narrow the scope of the study and to ensure that the study gathers relevant information and presents it in an appropriate format. 


\section{A new vision for protected areas}

At the 1992 Earth Summit, the governments of the world agreed on a new agenda for sustainable development. This agenda included a bold new Convention on Biological Diversity (CBD) which, inter alia, calls on governments to establish systems of protected areas and to manage these in support of conservation, sustainable use and equitable benefit sharing. The governments recognised protected areas as economic institutions which have a key role to play in the alleviation of poverty and the maintenance of the global community's critical life-support systems. This new vision for protected areas requires an awareness and understanding of the economic values generated by protected areas.

\subsection{The global mandate for protected areas}

A protected area is "an area of land and/or sea especially dedicated to the protection and maintenance of biological diversity, and of natural and associated cultural resources, and managed through legal or other effective means" (IUCN, 1994). A protected area may be a wetland, a tropical or deciduous forest, a cultivated landscape of value, an alpine region, a savannah, a marine area or any number of other types of natural or partially modified ecosystems - or indeed any combination of types of ecosystems. In addition to covering an array of ecosystem types, protected areas are defined in a number of different ways relevant to the objectives and values for which they are managed. Box 1 highlights these various definitions as they apply to IUCN's categories of protected areas.

Traditionally one of the most widely used and, arguably, most effective tools for achieving conservation goals, protected areas today play a significant role in supporting local, national, and international biodiversity policies. They also serve as places for scientific research, wilderness protection, maintenance of environmental services, education, tourism and recreation, protection of specific natural and cultural features, and sustainable use of biological resources.

The importance of protected areas is emphasised by international conventions and programmes such as the CBD, the World Heritage Convention (WHC), the Ramsar Convention on Wetlands, the UN Law of the Sea Convention, UNESCO's Man and the Biosphere (MAB) Programme of the United Nations Educational, Scientific and Cultural Organisation (UNESCO) and the global programme of WCPA. Together these agreements and programmes are the backbone of international policy on the establishment and management of protected areas for biodiversity conservation and the sustainable use of natural and cultural resources. 


\section{Box 1. Six categories of protected areas}

\section{Category I}

An area of land and/or sea possessing some outstanding or representative ecosystems, geological or physiological features and/or species available primarily for research and/or environmental monitoring. A wilderness area is a large area of unmodified or slightly modified land and/or sea retaining its natural character and influence without permanent or significant habitation which is protected and managed so as to preserve its natural condition.

\section{Category II}

A natural area of land and/or sea designated to (a) protect the ecological integrity of one or more ecosystems for present and future generations; (b) exclude exploitation or occupation inimical to the purposes of the area; and (c) provide foundation for spiritual, scientific, educational, recreational, and visitor opportunities all of which must be environmentally and culturally compatible.

\section{Category III}

An area containing one or more specific natural or natural/cultural feature which is of outstanding or unique value because of its inherent rarity, representative or aesthetic qualities or cultural significance.

\section{Category IV}

An area of land and/or sea subject to active intervention for management purposes so as to ensure the maintenance of habitats and/or to meet the requirements of specific species.

\section{Category V}

An area with coast and sea, as appropriate, where the interaction of people and nature over time has produced an area with significant aesthetic, ecological and/or cultural value and often with high biological diversity. Safeguarding the integrity of this traditional interaction is vital to the protection, maintenance and evolution of such an area.

\section{Category VI}

An area containing predominantly unmodified natural systems managed to ensure long term protection and maintenance of biological diversity while providing at the same time a sustainable flow of natural products and services to meet community needs.

Source: IUCN, 1994

The CBD is a particularly important endorsement of protected areas in that:

- it is globally accepted, with over 170 signatory nations adopting its objectives of conserving biodiversity, sustainably using biological resources, and equitably sharing benefits arising from this use; 
- it defines biodiversity broadly as the variability among living organisms at the genetic, species and ecosystems levels; and

- it presents a powerful array of actions and tools for implementing a global biodiversity agenda.

The CBD envisions a major role for protected areas in national plans for biodiversity. Article 8 calls for the establishment and maintenance of systems of protected areas. As experts, IUCN has given advice on the focus and design of national systems of protected areas - see Davey, A. G. (1998). Article 8 establishes global priorities and policies for the in-situ conservation of biodiversity and obliges Parties:

- to establish systems of protected areas or areas where special measures need to be taken to conserve biodiversity;

- to develop guidelines for the selection, establishment and management of protected areas or areas where special measures need to be taken to conserve biodiversity;

- to regulate or manage biological resources important for the conservation of biodiversity whether within or outside protected areas, with a view to assuring their conservation and sustainable use;

- to promote environmentally sound and sustainable development in areas adjacent to protected areas with a view to furthering protection of these areas; and

- to provide financial and other support for in-situ conservation.

The central role of protected areas in Article 8 is reflected in the decisions of the Conference of the Parties (COP). These emphasise the importance of protected areas in achieving biodiversity goals for forest, marine, coastal, and other ecosystems. For example, the third COP (November 1996) recommended that strategies for sustainable forest management be based on an ecosystem approach, which integrates conservation measures such as protected areas and the sustainable use of biological resources.

The WHC also provides a global foundation for protected areas by encouraging the identification, protection and preservation of the cultural and natural heritage around the world. The WHC is a mechanism for ensuring that globally important sites are protected and properly managed. Under the WHC, countries submit sites for inclusion on the World Heritage List of sites which are then eligible for funding from the World Heritage Fund. Thus this Convention provides countries with an incentive to create and maintain protected areas of global significance.

Further agreements and action in the international arena also support protected areas. The UN Law of the Sea provides the framework for establishing marine protected areas by allocating rights to territorial seas. The Ramsar Convention encourages mutual commitment from signatories in the designation of wetland protected areas important to waterfowl and which can also promote the "wise use" of wetland ecosystems. UNESCO's MAB Programme recognises protected areas as key components in the design and management of biosphere reserves and important tools for meeting sustainable use objectives. Through the implementation of the biosphere reserve 
concept, the programme provides an international framework to: (a) conserve natural and cultural diversity; (b) promote models of land management and of approaches to sustainable development; and (c) improve knowledge on the interaction between humanity and nature through research, monitoring, education and training.

IUCN's WCPA is the major global network of protected area specialists. The mission of WCPA is "to promote the establishment and effective management of a representative world-wide network of terrestrial and marine protected areas", as an integral contribution to the IUCN mission. The mission of IUCN is "to influence, encourage and assist societies throughout the world to conserve the integrity and diversity of nature and to ensure that any use of natural resources is equitable and ecologically sustainable". The main purposes of protected area management, as outlined by the WCPA, are: scientific research, wilderness protection, preservation of species and genetic diversity, maintenance of environmental services, protection of specific natural and cultural features, tourism and recreation, education, sustainable use of resources from natural ecosystems, and maintenance of cultural traditions and attitudes.

\subsection{The need for innovative approaches}

Strong as this international mandate may be, global conventions and programmes alone are not enough to ensure the continued existence of, and sufficient funding for, protected areas. In times of fiscal austerity and tightening government budgets especially in developing countries which are home to much of the world's biodiversity - traditional funding sources for protected areas are increasingly under threat. Innovative alternatives to these traditional sources are needed in order to secure the long term viability of protected areas. In addition to strengthening traditional funding, finding additional funding sources has the added benefit of diversifying a protected area's income sources. This makes the protected area more viable and helps it to withstand times of economic hardship.

Where does a protected area manager look for alternative funding sources? What do these potential supporters want from the protected area? And what does the protected area manager communicate to these supporters? Valuation can help the protected area manager find the answers to these questions, and more.

The process of valuation provides protected area managers with information about the protected area's goods and services, the values which people (potential supporters or customers) place on those, which values are being captured and which are not, and which groups could derive more benefits through alternative uses of the protected area and are therefore inclined to be a 'threat' to the protected area. In this way, valuation provides useful information for management and financing decisions regarding protected areas.

A thorough scoping stage of a valuation study identifies the array of benefits flowing from the protected area and the people who value those benefits. This information is likely to expose those who are not contributing to the protected area but derive benefits from it (and are therefore potential sources of funding), as well as those who are 
excluded from deriving benefits from the protected area but are being asked to 'pay' for the protected area, e.g. through taxes, property loss or foregone opportunities.

For instance, a protected area manager searching for additional financing may realise, in the preliminary stages of a valuation study, that the protected area is not capturing any of the value held by bird watchers using the area. To capture this, the manager might decide to start renting out binoculars and bird-books or to start a fund directed at donations from bird-watchers earmarked for bird conservation efforts. On the other hand, if the bird-watchers are a low-income group and unlikely to be able to pay for the benefits they receive, the protected area manager may approach a potential donor, such as the Royal Society for the Protection of Birds or the Ramsar small projects fund, which may be willing to be a benefactor for the bird-watching group. By knowing the benefits and the groups receiving these benefits, alternative avenues for funding protected areas are indicated.

In another instance, a protected area manager might find that neighbouring people are not deriving any benefits from the protected area and, in fact, have been forced to forego opportunities of using the land for agriculture, forestry or other uses due to the establishment of the protected area. This manager needs to look for alternative management practices that enable the protected area's neighbours to derive some benefit from the presence of the area without compromising its overall conservation objectives, thereby reducing the pressure to convert the land to other uses. Alternatives may be to open the protected area to sustainable harvesting of forest products or to develop local capacity to service tourists visiting the protected area. In this case, identifying marginalised groups and the benefits that they have foregone helps the manager solve conflicts and thus reduce threats.

The possibility of looking for alternative management practices depends on different factors that should be considered as part of the valuation process:

- What is the management category for the area? A Category V or VI protected area has the potential to accommodate a wide range of uses by zoning the resources within the area. A Category I area offers a much more limited array of use options such as research.

- Is the protected area well managed? Capturing the values attributed to a protected area in turn requires the capacity to manage that area to maintain these values.

- Is the protected area attractive enough? As this paper explains there are a number of different kinds of values attributable to protected areas. Tourism and recreation values are particularly attractive to managers because they are relatively easy to capture and because they can be a source of significant funds. But some areas may not have the ability to draw tourists. An economic valuation study conducted at a national level can indicate which areas are most able to obtain funding from tourists and which are not. A system of cross-subsidisation, or a separate funding strategy, can then be used to support wildlife which may be biologically important, but with little appeal to tourists.

Such management and finance decisions are not limited to the local protected area manager. Often decisions, such as increasing access fees and the opening up of areas for new tourist concessions, are considered under national or provincial laws and 
regulations on protected areas. The valuation process, however, can inform decisions taken at national and international levels and should provide recommendations on how to enhance the national legal framework for protected areas management.

All governments have limited resources to spend on services for their citizens and must make decisions about how and where to spend these resources. Sectors within government compete for a share of the fiscal budget. Thus protected areas compete with development programmes, health and welfare services, education, and the military, and so forth. Valuing protected areas can provide the economic reasons, to complement the biodiversity ones, why governments - and others - should invest in them.

\subsection{The client approach}

Governments, donors, tourists and local people decide what goods and services to buy with their money. In economic terms, such groups are the real or potential 'customers' of the goods and services of protected areas: they are the 'clients' of the protected area. Since protected areas supply goods and services in a generally competitive marketplace they are, in an economic sense, businesses facing a complex array of customers who may wish to spend their limited funds elsewhere.

A business is in business to make profits. It makes profits by selling goods and services to customers at a price marginally higher than the cost of producing these goods and services. Though a protected area is in the business of providing biodiversity services, it can use a business approach - profit-centred and entrepreneurial so as to maximise its financial capacity to achieve conservation aims.

To illustrate this client approach, consider some examples of protected areas - a wildlife sanctuary in South Asia, a savannah park in southern Africa, a forest reserve in South America, a protected landscape in Europe or a marine protected area in the South Pacific. All such areas provide a stream of goods and services (benefits) to a host of customers (those who hold a value for the benefits).

What benefits do such protected areas generate and to whom? Are these benefits and their distribution sufficient to ensure that the protected area will be conserved? In particular, do these benefits result in adequate financial flows to maintain the protected area? If not, what measures are needed to generate revenues for managing this protected area and achieve the conservation and development objectives of the protected area?

Think of the customers of the protected area. Think of its neighbours and those living within it as customers. What goods and services do they want from the protected area? Timber to convert into charcoal for fuel? Non-timber products such as fruits and honey? Medicinal plants? Thatching grasses? Do they want access to lands for grazing their livestock or to watering holes during the dry season? Do they want to have access to coral reefs for seafood? What measures are necessary to ensure that the uses they make of protected area resources are sustainable and that they pay for the goods and services provided by the protected area? 
Should the neighbouring or resident community be involved in a collaborative management scheme? Can a system of tradable harvesting permits for timber, honey, fish or grasses be developed? What about access rights for grazing, hunting, or watering? How can support be maintained for traditional land use practices which conserve biodiversity?

Alternatively, think of neighbours or residents as a direct threat to the protected area. Their interest in protected area land for intensive farming or ranching may outweigh their interest in conserving the protected area. Is it in their immediate economic interest to convert the protected area to other uses that threaten biodiversity? If so, why? Are there existing measures, such as agricultural or prospecting subsidies or poorly-defined access rights to wild resources, which threaten biodiversity? Are such "perverse incentives" actually encouraging neighbours to destroy the protected area? Are there positive incentives which can be put in place instead?

Now think of commercial customers of the protected area. What goods and services can be harvested sustainably from the protected area and sold on the open market? Tourism, of course, is often an important non-consumptive service. What about the commercial sales of timber and non-timber products, including medicinal and ornamental plants, honey, bush meat, and so on? Does the protected area offer opportunities for hunting or fishing? Is it a prime site for bio-prospecting? Are there potential genetic resources to be harvested? How can such commercial operations be structured to generate revenues for the protected area so as to support the overall goal of biodiversity conservation?

Additionally, there are probably downstream or indirect customers of the protected area. What benefits accrue to downstream communities and enterprises or more generally to the entire country or region? If the protected area serves as a watershed, it provides benefits to downstream water users including farmers, ranchers, miners, manufacturers and villagers. If it is an area visited by people from cities nearby, then it offers a range of benefits (recreational, educational etc.) to urban dwellers. These groups have a stake in conserving the protected area, but do they have any means to express that interest? What measures will encourage and enable them to support the protected area? Can fiscal measures be used to collect revenues from these downstream customers?

Also, consider the global customers of this protected area. Within the mandates of global environmental agreements, the protected area may provide several global benefits. These could include biodiversity conservation, carbon sequestration, habitat for endangered species and migratory species, replenishing fish stock for traditional and commercial fisheries, mitigation of natural disasters and impacts related to climate change, and so on. What measures will enable the global community to support the protected area? Can the Global Environmental Facility (GEF) be used as a means of finance in such cases?

In short, a protected area can provide a diverse array of biological goods and services to a diverse array of customers. Bringing an entrepreneurial, private sector perspective to protected area management - in the first instance, by thinking of customers for protected area products - can help the protected area to sell goods and services in a way 
that will strengthen the ability of the protected area to support the conservation of biodiversity and sustainable use of natural resources. Valuation is a tool which can help protected area managers to start thinking like a business manager by providing a structured approach for identifying real and potential customers, estimating appropriate prices for goods and services, and signalling ways of capturing those prices. 


\section{Economic values of protected areas}

Identifying a protected area's goods and services, determining who values those goods and services, and measuring these values is not always a straightforward process. The goods and services include recreation and tourism, plant and wildlife habitat, genetic resources, water supply, protection against natural disasters, and so on. Many of these goods and services are not traded on commercial markets and therefore have no evident market value. The values of non-market goods and services need to be measured and expressed in monetary terms, where possible, so that they can be weighed on the same scale as commercially traded components.

The concept of total economic value (TEV) is now a well-established and useful framework for identifying the various values associated with protected areas. The total economic value of a protected area consists of its use values and non-use values. A protected area's use values are in turn made up of its direct use values, indirect use values, and option values. Non-use values include bequest values and existence values. Box 2 illustrates the relationships between these values, and these terms are explained below.

\section{Box 2. Total economic value}

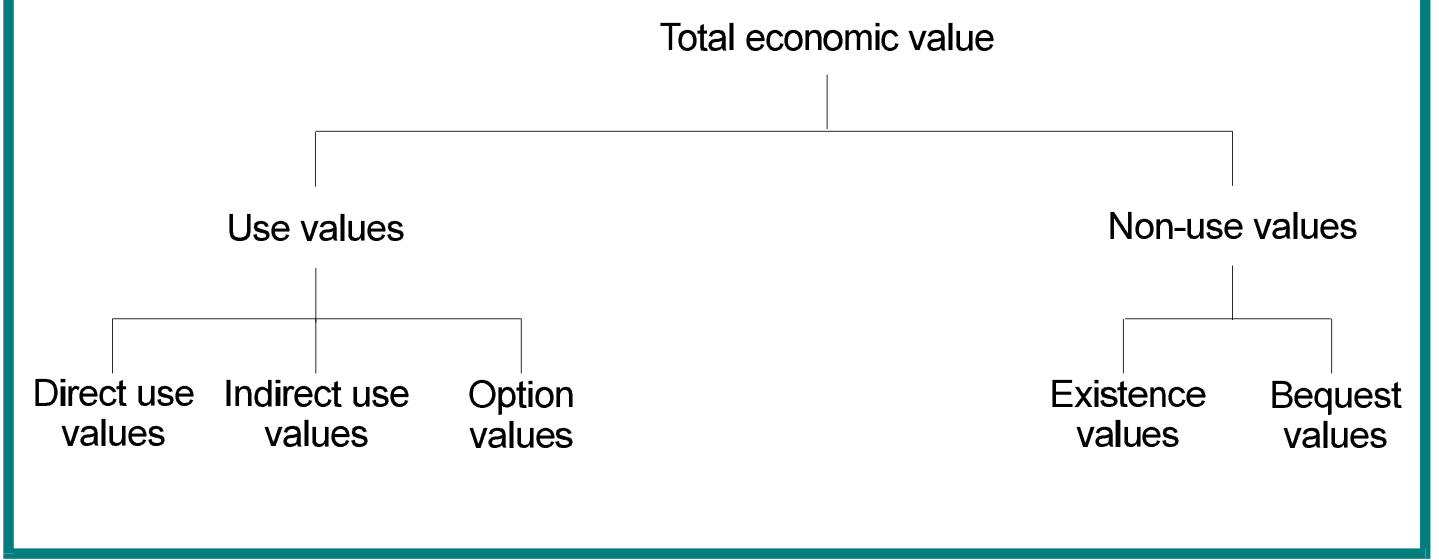

The difference between economic valuation and financial analysis should be made clear at this stage. Economic valuation, based on economic value, measures market and non-market values that people hold for a protected area. Financial analysis is a subset of economic valuation and measures the flow only of money through a protected area. Box 3 depicts the relationship between the two. Though financial analysis is a very useful tool, it may not be the most appropriate for all situations. This guide uses economic valuation as a framework because it captures a broader array of values. 


\section{Box 3. Economic valuation and financial analysis}

\begin{tabular}{|l|l|}
\hline \multicolumn{2}{|c|}{ Economic valuation } \\
\hline Protected area & External \\
& $\vdots$ \\
\hline Financial analysis & \\
& \\
& \\
\hline
\end{tabular}

The direct use values of a protected area are values derived from the direct use of the protected area for activities such as recreation, tourism, natural resource harvesting, hunting, gene pool services, education and research. These activities can be commercial, meaning they are traded on a market (resource harvesting, tourism and research), or non-commercial, meaning there is no formal or regular market on which they are traded (fuelwood collection and informal grazing). The value of commercial uses will generally be a straight-forward process of directly obtaining market-priced values. However, if these prices are administratively set, they may not reflect the true value for the product. Valuing non-commercial uses is more complex and entails a range of techniques which solicit values for goods and services of a roughly comparable nature from other markets.

The indirect use values of a protected area are values derived from the indirect uses of the protected area. Indirect uses are largely comprised of the protected area's ecological functions such as watershed protection, breeding habitat for migratory species, climatic stabilisation and carbon sequestration. Protected areas also provide natural services, such as habitat for insects which pollinate local crops or for raptors which control rodent populations. Indirect use values are often widely dispersed and thus go unmeasured by markets. Alternative valuation techniques discussed later are necessary for measuring them.

The option values of a protected area are values derived from the option of using the protected area sometime in the future. These future uses may be either direct or indirect and may include the future value of information derived from the protected area. Future information is often cited as particularly important for biodiversity as untested genes may provide future inputs into agricultural, pharmaceutical or cosmetic products.

Non-use values are values which humans hold for a protected area which are in no way linked to the use of the protected area. Two common examples of non-use values are bequest values and existence values. Bequest values relate to the benefit of knowing that others benefit or will benefit from the protected area. Existence values reflect the benefit of knowing that the protected area exists even though one is unlikely to visit it or use it in any other way. Non-use values are particularly difficult to measure. Box 4 provides examples of each of the types of values attributed to protected areas. 


\section{Box 4. Total economic values of protected areas}

\begin{tabular}{|c|c|c|c|c|}
\hline \multicolumn{3}{|c|}{ Use values } & \multicolumn{2}{|c|}{ Non-use values } \\
\hline $\begin{array}{l}\text { Direct use } \\
\text { value }\end{array}$ & Indirect use value & Option value & Bequest values & Existence values \\
\hline Recreation & Ecosystem services & Future information & $\begin{array}{l}\text { Use and non-use } \\
\text { values for legacy }\end{array}$ & Biodiversity \\
\hline $\begin{array}{l}\text { Sustainable } \\
\text { harvesting }\end{array}$ & Climate stabilisation & $\begin{array}{l}\text { Future uses (indirect } \\
\text { and direct) }\end{array}$ & & $\begin{array}{l}\text { Ritual or spiritual } \\
\text { values }\end{array}$ \\
\hline $\begin{array}{l}\text { Wildlife } \\
\text { harvesting }\end{array}$ & Flood control & & & Culture, heritage \\
\hline Fuel-wood & $\begin{array}{l}\text { Ground-water } \\
\text { recharge }\end{array}$ & & & Community values \\
\hline Grazing & Carbon sequestration & & & Landscape \\
\hline Agriculture & Habitat & & & \\
\hline $\begin{array}{l}\text { Gene } \\
\text { harvesting }\end{array}$ & Nutrient retention & & & \\
\hline Education & $\begin{array}{l}\text { Natural disaster } \\
\text { prevention }\end{array}$ & & & \\
\hline Research & $\begin{array}{l}\text { Watershed protection } \\
\text { Natural services }\end{array}$ & & & \\
\hline
\end{tabular}

The values which appear in italic in Box 4 are likely to be particularly important to protected areas.

This guide has adopted a TEV approach for identifying the array of values that are attributed to protected areas because of its holistic perspective of values. But the reader should keep three things in mind about TEV:

1. TEV is anthropocentric in that the values in the TEV framework are human-held values. The framework does not account for possible intrinsic values of biodiversity. There is a continuing debate within the conservation community over whether nature in general, and species in particular, have values unrelated to humans. This guide recognises that economics cannot fully account for all the values attributed to protected areas or the species reliant on them;

2. there are likely to be conflicting values identified through the TEV. This is because people may very well hold more than one type of value for the goods and services attributed to a protected area which are in potential conflict. One person may value the viewing of an elephant in its natural habitat, while another may value harvesting or hunting the elephant. Any attempt to calculate an actual total economic value for a protected area is likely to be burdened with problems of missing values, conflicting values and double counting; and

3. undertaking a full TEV study is usually unnecessary. Such an extensive exercise would be very costly, time-consuming and difficult. The park manager should be sure however to have measured the values which are most important for his/her needs. Just what kinds of arguments can be made with valuation studies and which values are needed for such arguments is the subject of the next section. 


\section{A framework for valuing protected areas}

Identifying the values which people hold for a protected area may be an interesting intellectual exercise, but without a framework which embeds the values in a broader context, the process is just that - an exercise. A structured assessment process gives purpose and direction to a valuation study and saves time and money in the end. Such a process identifies what the values will be used for, which values are important to measure, and which techniques of valuation are most appropriate. The assessment process proposed in this section involves three basic steps:

1. Define the audience.

2. Determine the scope of the study.

3. Choose the appropriate analytical techniques.

The decisions taken in these steps are interrelated in that the interests of the audience will help to define the scope of the study and the scope will dictate, to some extent, the relevant techniques. Box 5 provides some general guidance about how the audience, the type of analysis and the scope of the study relate.

\section{Box 5. Analytical matrix for protected areas}

\begin{tabular}{|l|l|l|}
\hline Audience & Analysis & Scope \\
\hline local & financial/economic & local area \\
\hline national & financial/economic & national \\
\hline global & economic & international \\
\hline
\end{tabular}

\subsection{Define the audience}

Before starting a valuation study, the end use and audience for that study need to be determined. Defining the eventual use of the valuation study gives the study a raison d'être, enables it to be carried out efficiently and effectively, and ensures that the information arrived at is relevant and clear to those who must use it.

Valuations can be used to procure support for the continued existence of protected areas. But a valuation study can also inform decisions about the management or financing of the protected area. There are many types of decisions which are made by many different groups. Decisions are made about:

- designing and carrying out projects in or adjacent to protected areas; 
- designing and carrying out projects which use protected area goods or services;

- designing and carrying out projects upstream to, or downstream from, protected areas which may impact them;

- establishing and implementing sectoral programmes relating to protected areas;

- establishing and implementing policies for protected area management;

- establishing and implementing policies for protected area financing; and

- designing strategic plans at local, regional, national and international levels.

These decisions are made by protected area managers, community members, government officials, sectoral ministries, private enterprise, donor agencies, NGO's, the international community, and more. A brainstorming session with the economist and relevant stakeholders may help the protected area manager to identify the type of decision to be made and the groups that need to be involved.

The type of decision and the nature of the stakeholder groups help determine which values need to be measured and how those measurements should be expressed. For instance, a decision about carrying out a construction project adjacent to a protected area requires information about a set of values different from those needed for a decision about how much global funding to seek in support of maintaining biodiversity in a protected area. Additionally, a group involved in the public enquiry of the construction project will need the information presented in a manner different from a ministry of finance or the GEF.

The perspectives of the relevant stakeholder groups will also influence what is considered a benefit and what is a cost. Assigning the title of benefit or cost is ultimately a subjective process. One person's costs may be another person's benefits. In some cases it may be necessary for a protected area manager to represent what is a 'cost' to taxpayers (civil service jobs) as a 'benefit' to a particular constituency (local communities).

Valuation studies can be expensive and time consuming. But not only is it unlikely to be necessary to measure all the values for a protected area, the values arrived at will not be valid for long. Values which people ascribe to a protected area are like preferences and prices, and thus are likely to change over time. Tailoring the valuation study to suit the particular needs of the decision at hand and the targeted stakeholder groups will make for a more efficient and effective study.

\subsection{Determine the scope in terms of the time, data, resources and institutional structure}

Having determined what the valuation information will be used for and who will use it, the next step is to determine the appropriate scope for the study. The scope of the study must be defined in geographical, temporal and subject terms.

It is necessary to know what geographical area the valuation study should cover. Protected areas can cover a vast area of land or water, not all of which may be relevant 
to the decision-making process. For instance, if a local planner needs to know the impact of an infrastructure project proposed for a site on the north-east corner of the protected area then it is probably unnecessary to measure values of unimpacted goods from the south-west corner. On the other hand, an international donor agency which needs information about the protected area's contribution to the global climate change mitigation is likely to need values relating to the carbon sequestration services of the entire protected area, but not the values of viewing its predators by tourists.

Also, for a valuation study to be relevant, there needs to be a clear idea of the timeline involved in the decision-making process. A valuation study that arrives two years after decisions have been taken is irrelevant - no matter how valid the data. Likewise, the decision-makers using the valuation study need to be realistic about time limitations they impose on the study. The time required to conduct a valuation study depends on the types of benefits being measured, the state and relevance of existing data, the level of measurement required, the amount of certainty desired, the capacity to conduct the study, and so forth. Protected area managers must be realistic about their demands - it is unlikely, for example, that a full contingent valuation study can be done in three weeks - and if time is short, then expectations should be realistic.

Finally, it is important to define the scope of the study in subject terms. That is to say, the scoping stage of the study must identify exactly which values are relevant and should be (and can be) measured. As pointed out in Section 2, people ascribe many types of values to protected areas. The first step to determining which values are relevant is to get a broad idea of the benefits attributed to the protected area and the people who value those benefits - or in other words, the people who are stakeholders in the protected area.

The process of conducting this broad scoping exercise is itself a useful tool for internal management and finance decisions. This is because identifying the various values people hold for the protected area and the groups that derive benefits from the protected area highlights opportunities for obtaining revenues, improving services and minimising exposure to threats. Often the actual measurement of all or some of the values is unnecessary.

Of course, not all values identified through this broad scoping process are relevant to every decision. The next task in the scoping process is determining which values are relevant to the end decision. The type of decision will influence the ranking of the values. For instance, a decision about the impact of a development project on the protected area needs information about the values of goods or services affected by the project - therefore measuring these values should be a priority. On the other hand, a decision regarding alternative uses for the protected area needs information about the most important goods and services that would be foregone if an alternative use were chosen.

It is also important to consider the likelihood of being able to measure the values, and the costs of measuring them. As mentioned before, time and money are likely to be constraints on the study and may limit the types of values which can be measured. This is linked to the next stage in the framework - identifying methods of data collection because the methodologies used will influence the time required and costs involved. 


\subsection{Choose the analytical technique}

Measuring the direct use values which are traded on commercial markets is likely to be a more straightforward process than measuring the other values attributed to protected areas. This is because the markets have already done the work of eliciting values from the 'customers' of the protected area. The task of measuring these values involves identifying the markets for them, gathering data about prices paid in these markets, and determining the amount of the good or service traded on the market. For instance, the direct use values of tourism could be measured through the direct sales to tourists which may include expenditures on lodging and meals, entrance fees, concessions, rentals, guides and so on. Where prices such as entrance fees are administratively set and not market driven, however, it may also be necessary to estimate the likely market prices.

The markets where some of the direct values associated with protected areas are measured are given in the middle column of Box 6. Indicative methods available to protected area managers for capturing these values are given in the right column. These include collecting rents from those regularly using the land, applying user fees through systems such as hunting or camping permits, charging for access to the land or resources and so on.

\section{Box 6. Markets and some means of capturing direct use values}

\begin{tabular}{l|l|l}
\multicolumn{1}{c|}{ Benefit } & \multicolumn{1}{c|}{ Market } & \multicolumn{1}{c}{ Capturing the values } \\
\hline sustainable harvest & $\begin{array}{l}\text { income from sales, market prices } \\
\text { for similar goods, proportion of } \\
\text { income from final products }\end{array}$ & user fees, access charges \\
\hline recreation & tourism expenditures & gate fees, concessions, rents, tax \\
\hline education & $\begin{array}{l}\text { price of alternative courses on offer } \\
\text { elsewhere }\end{array}$ & user fees, interpreter fees, gate fees \\
\hline scientific & $\begin{array}{l}\text { proportion of income from final } \\
\text { research products }\end{array}$ & access charges \\
\hline national ecosystem services & price of alternative service & tax, user fees \\
\hline
\end{tabular}

A study which arrives at a value by tracing the flow of money through the official market is termed a financial analysis. A protected area's contributions to the financial transactions of the economy are its financial values. Values which fall outside of these financial transactions - such as many non-use and indirect use values -would not be included in a financial analysis. As is revealed in the case studies in Part II, these are the very values which often contribute significantly to the overall economic value of protected areas.

As emphasised before, the type of decision which the valuation information will be used for, and the people making the decision, have a significant influence over the nature of the valuation study. In fact, the group making the decision may hold a set of priorities far different from the protected area manager and the study may take on an 
entirely different perspective because of this. For instance, the Money Generation Model - used by the US National Parks Service to inform local communities of the value of nearby parks - counts jobs and local tax revenues generated by the park among the benefits attributed to it. Treating jobs as benefits can be rational from the perspective of the local community which may indeed see local jobs created by the park and local tax revenues derived from expenditures in the park as direct and indirect benefits attributable to the park. But from the perspective of the park manager who is running the park like a business, jobs and taxes are costs, not benefits. Taxes are, of course, also a cost to the taxpayers.

It is important to know the priorities of the group which will be using the valuation information as this will further affect which values are chosen and how they are presented. For instance, a local community is likely to be more interested in the number of local jobs created by the protected area, rather than the total number of jobs created. On the other hand a national government will be interested in considering employment prospects overall.

Employment may also take on a different significance when the ratio of foreign specialists to local workers is considered. In comparing protected area employment to other uses for which the area could be considered, a preference for work offered to local people may provide added support for the protected area. Alternatively, as is common in many developing economies, emphasis may be placed on the hard currency earnings and this becomes a determining factor.

The process of the Money Generation Model is detailed in Box 7 along with some means of adapting the model for international use. As this model is specifically addressing a local community decision of whether or not to support the protected area, it may not provide much useful or appropriate information for a Ministry of Finance deciding how much national funding to allocate to the protected area. Indeed, national government expenditure on the protected area is measured as a benefit in the Money Generation Model rather than as a cost. Nevertheless, such a model offers a simple approach to capturing some of the values of a protected area, for site-specific, local audience situations.

Where markets do not exist, values held by 'customers' must be elicited. An array of methods for eliciting both market and non-market values from people for environmental goods and services have been developed over the last few decades. Though still a developing field, some of the more common and widely used methods include:

- contingent valuation,

- hedonic pricing,

- travel cost method,

- change in productivity,

- loss (or gain) of earnings,

- opportunity cost, and

- replacement cost. 


\section{Box 7. The Money Generation Model}

The Money Generation Model uses protected area-related expenditures from non-local tourists and Governments to determine the neighbouring communities' benefits in terms of jobs and tax revenues. An example from a study of Federal Interest Lands in South Florida done by FAU/FIU Joint Center for Environmental and Urban Problems (Correia, 1995) is used here to demonstrate the model.

\section{Tourism}

A. Sales benefits

1. Estimated non-local $\%$ of protected area use . . . . . . . . . . . . . . . . $90 \%$

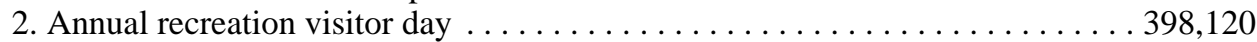

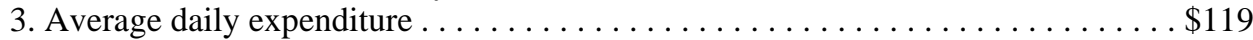

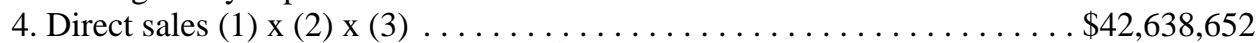

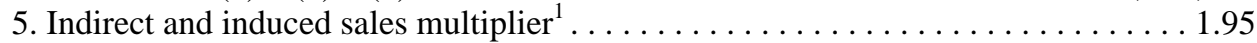

6. Sales benefits from tourism (4) $\mathrm{x}(5) \ldots \ldots \ldots \ldots \ldots \ldots \ldots \ldots \ldots \ldots \ldots \ldots \ldots \ldots, 145,371$

B. Tax revenue benefits from tourism sales

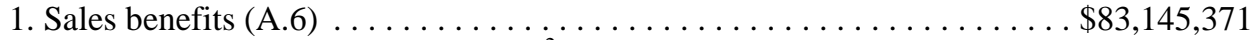

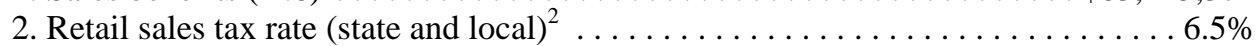

3. Sales tax revenue benefits from tourism . . . . . . . . . . . . \$5,404,449

C. Job benefits from tourism sales

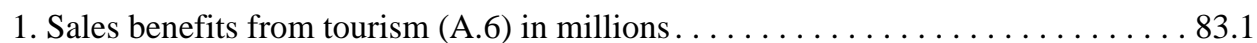

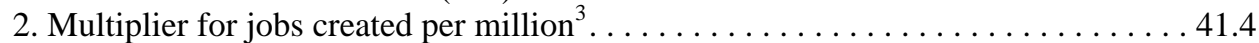

3. New jobs from tourism sales. . . . . . . . . . . . . . . . . 3,440

\section{Federal government expenditures ${ }^{4}$}

A. Sales benefits

1. Direct sales . . . . . . . . . . . . . . . . . . . . . . . . . . . . \$ $\$ 18,021,448$

2. Indirect and induced sales multiplier ${ }^{1} \ldots \ldots \ldots \ldots \ldots \ldots \ldots \ldots \ldots \ldots \ldots$

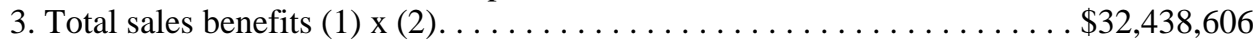

B. Tax revenue benefits from government related sales

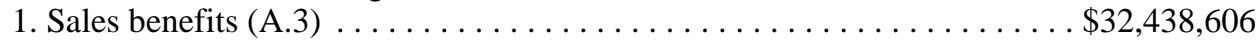

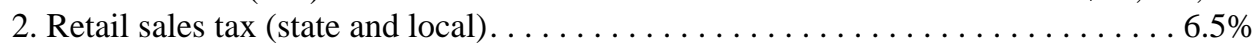

3. Sales tax revenue benefits $(1) \times(2) \ldots \ldots \ldots \ldots \ldots \ldots \ldots \ldots \ldots \ldots \ldots \ldots \ldots \ldots$

C. Job benefits from government related sales

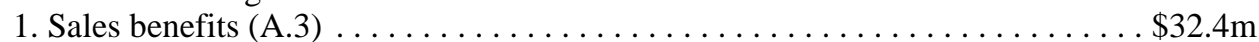

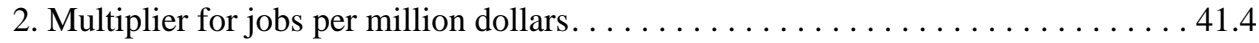

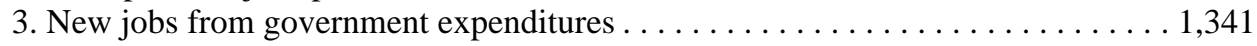

${ }^{1}$ Indirect and induced sales multipliers (usually $1.2-2.8$ for the US) vary with the complexity of the local community. More isolated areas are likely to have lower multipliers because a larger portion of spending will be conducted outside the area. If this multiplier is small, one option for the community is to devise ways of providing more services and goods for tourists in the area.

${ }^{2}$ The US retail tax system is comprised of state and local taxes. This is unlikely to be the case in many countries and the level of government collecting retail taxes will affect whether or not they can be considered 'local' benefits.

${ }^{3}$ The jobs multiplier will vary from industry to industry and range from 10 to 50 per million dollars in total sales in the US tourism industry. Additionally, rural areas tend to have larger jobs multipliers than towns and cities.

${ }^{4}$ The procedures for calculating the job and tax revenue benefits 'non-local' (State) government expenditures in the protected area follow these Federal Government expenditure procedures. Managers in developing countries may consider including Donor and International Government expenditures in this model.

Source: Adapted from US National Parks Service 1995-1996 
The contingent valuation method $(\mathrm{CVM})$ uses a direct approach to valuing an environmental good or service in that it asks people through surveys or experiments what they are willing to pay for the good or willing to accept for the loss of the good. The concepts of willingness to pay (WTP) and willingness to accept (WTA) and the issues surrounding their use are discussed in Box 8. Contingent valuation is particularly attractive because it can estimate values where markets do not exist or where market substitutes cannot be found. For these reasons, CVM is widely used to measure existence values, option values, indirect use values and non-use values.

Hedonic pricing uses existing markets - such as the housing or labour markets - to determine the value of an environmental good. The assumption is that property values or wages reflect a stream of benefits, some of which are attributable to the environmental good. The analyst's task is to isolate that value which is attributable to the good. Hedonic pricing can be used to establish some of the more aesthetic values of protected areas as residential property adjoining a protected area is likely to hold a higher value because the protected area is viewed as a benefit. On the other hand, hedonic pricing can be used to value environmental damages, and their effects on property values or wages. Hedonic pricing becomes problematic where alternative markets are distorted or where information about environmental products is not widespread and data are scarce.

Travel cost method also uses existing markets, determining a person's value of an environmental good from what they spend on travelling in terms of time, travel expenditures and entry fees. Travel cost methods are particularly useful for assessing

\section{Box 8. Willingness to pay and willingness to accept}

People reveal their value for the benefits derived from a protected area through their willingness to pay (WTP) for those benefits. A person's WTP can be elicited through surveys or surrogate markets. People also reveal their value for an environmental benefit through their willingness to accept (WTA) compensation for foregoing the benefit. In the case of environmental loss, people reveal their values through a willingness to pay to prevent the loss and their willingness to accept compensation to tolerate the loss.

These two concepts of benefit, WTP and WTA, should reveal the same values for the protected area. But empirical studies suggest this is not the case. It is generally believed that this is because people value the things they have more than those things they do not have. Therefore WTP is usually smaller than WTA.

An additional problem arising from the concept of WTP in practice is that people with high incomes can afford to pay more than those with low incomes. This is particularly problematic when valuing a protected area in a developing country which is used by developed country tourists because the tourists will be able to place a higher value on their use and non-use benefits than the local people. In order to compare two such sets of value it may be necessary to measure the two sets of values as a percentage of income. Such a split may also support segmented pricing for local and foreign tourists as is increasingly common in developing countries. 
the non-commercial tourism, recreation and leisure values of a protected area. Travel cost methods, however, can be problematic in that they are data intensive, they rely on restrictive assumptions about consumer behaviour (e.g. multifunctional trips), and they are highly sensitive to the statistical methods used.

Change in productivity methods value the goods and services of a protected area by estimating the change in the value of production of a good or service that occurs as a result of the change in land of the protected area. Measuring the change in productivity is particularly useful when trying to discover the ecological values of a protected area. To take an example, a forested protected area is being considered for a clear-cutting operation. As it stands, the forest provides a service to farmers downstream by keeping the river from silting up. The change in productivity method would measure the current level of productivity and estimate its level after the clear-cutting, and calculate the difference between these levels to derive the loss in productivity. This loss is then a value of the protected area as it correctly stands.

Loss (or gain) of earnings methods evaluate the change in productivity of humans resulting from environmental deterioration (or improvement). Such methods may be useful in determining some of the more concrete effects of a change in the regulatory functions of protected areas. These regulatory functions include watershed protection, storage and recycling of organic matter, nutrients, and human waste, and climate regulation. For example, if water quality improvements reduce the levels of disease resulting from poor water quality, then the loss-of-earnings approach can be used to estimate benefits of clean water.

The opportunity cost approach provides an estimate of the value of a protected area based on the foregone income of the best alternative use of the area. Measuring the opportunity cost of the protected area can give the manager an idea of the competitive threats to the area. In the case of potential threats from people living adjacent to a protected area, the relevant opportunity costs will be the value of alternative land uses they may prefer, such as farming or ranching. Other interest in the area may come from pressures for industrial or urban development, mining or intensely modified recreation uses.

The replacement cost approach can be used to measure the cost of damage done to the protected area by looking at how much it would cost to replace the assets that are damaged. For example, the cost of restoring a protected area could be used as an estimate of the cost of environmental damage to the protected area. These costs are then compared to the costs of preventing the damage in the first place. If the replacement costs exceed the prevention costs then the damage should be avoided.

Case studies in Part II use these and other related methods to determine protected area value. As is evident from the cases, the methods used for a valuation study largely depend on the specific situation of that study and will likely be adapted for the study's specific needs. The methodology for valuing environmental goods and services is continually developing. New methods are devised and old ones amended with every study that is conducted. Deciding on the methods which suit the needs of the study requires imagination and ingenuity. Those described in this section should not be seen as all inclusive, but as an introduction to the possible approaches to valuing protected areas. 


\section{Conclusion}

The potential uses of economic valuation for protected area managers are certainly great and varied. Hopefully this guide has given managers the encouragement and information they need to enlist the skills of a professional economist and embark on a valuation study of their protected area. As has been made explicit throughout this guide, though, such a study must be designed and carried out with a specific purpose in mind. A valuation study will be most useful, effective and efficient when it has a clearly defined purpose and audience - whether it is to secure funding for global ecosystem services from the GEF, to present an economic rationale for a share of the national

\section{Resource Economics within the Natal Parks Board}

The Natal Parks Board started the development of its own resource economics expertise some five years ago. At that time, one of our prime protected areas was subject to a mining threat. We felt that unless we would be able to develop sound economic arguments in defence of nature conservation and tourism as a land-use option, we would have difficulties fighting off the threat, and any other future threats that could be anticipated in South Africa's transforming society.

After five years, resource economics is routinely assisting the Board in decision-making by assessing economic values of conservation benefits, and their distribution spatially and among stakeholders, and by recommending ways to optimise these values. The latter can lead to more efficiency by enhancing the economic contribution of protected areas, or to more fairness by creating a more equitable distribution of benefits and costs among stakeholders and regions.

Resource economics perspectives are used at two levels: general advocacy and management support. General advocacy is needed to raise the awareness among political decision-makers and policy makers of the fact that conservation creates a myriad of monetary and non-monetary benefits to a variety of stakeholders, the overall sum of which exceeds the opportunity costs of the state subsidy. Policy and management decisions at all levels draw on resource economic perspectives to quantify the benefits and costs of alternative options, such as various tourism development strategies and pricing policies.

Finally, and perhaps most importantly, the value of resource economics to the Board is reflected in the integration of resource economic thinking and capacity into decision-making at all levels, which ensures that well-balanced and innovative approaches are developed towards the achievement of nature conservation objectives. 


\section{Economic Assessment and Parks Canada}

The use of an economic impact assessment to help determine the feasibility of establishing a proposed national park is now accepted as being an important tool for decision makers in Canada. Quite often in the past, from an economic perspective, we found that it was difficult to argue that establishing a national park was a sound land-use decision. The park often faced other land use alternatives such as logging the area's forest, building a dam, or developing a mine, the kind of development projects for which the economic impacts are usually highly visible, often immediate, easily quantified and very appealing.

The ability to predict the economic impacts of a potential national park has proven useful in Canada. By providing decision makers at the local, provincial and national levels with a measurable estimate of the economic benefits that a national park can provide, we can offer stronger arguments for a park's establishment. Of particular importance to us in the business of establishing national parks is the ability of economic assessments to measure objectively and demonstrate such sustainable economic benefits as direct government spending, ecotourism, economic spin-offs to local and regional economies, local job creation, and so on. With this kind of information in hand, Parks Canada's conservation initiatives are better able to hold their own when compared to other land-use alternatives.

Moreover, with 15 new national parks and 25 national marine conservation areas yet to be established before these systems are considered complete, I am convinced that the use of economic valuation will continue to be an essential component of the park establishment process in Canada.

Bruce Amos

Director General, Parks Canada

budget or to identify and develop means for neighbouring communities to derive benefits from the protected area. It is therefore vitally important that the protected area manager understands the array of possible uses for economic valuation, identifies the specific use for a valuation study of their protected area, and conveys that information to the economist so that there is a strong and appropriate framework for the study.

It would be misleading to recommend a single, simple method which will address every issue of every study for every protected area. Instead this guide has attempted to give protected area managers the basic concepts of economic valuation, and a framework for starting to think about a valuation study. By defining the audience, determining the scope, and choosing the appropriate analytical technique, a protected area manager should be able to commission a practical and useful valuation study which will help to guide management and financial decisions. Valuation is a tool which can help protected area managers conserve and sustainably use biodiversity, and more equitably share the benefits derived from that use of biodiversity. 


\section{PART II}

This part of the Guidelines for protected area managers provides 16 examples or case studies of the process of valuation to help clarify the steps involved and highlight the ideas presented in Part I. Since each protected area is unique, stakeholders are interested in a different array of values. Each valuation exercise is itself therefore likely to be unique. Nonetheless, learning from practical experiences is probably the most useful way to understand in full how valuation can be used for a protected area and what a valuation study may entail in terms of resources, data and time. 


\section{Valuation study examples}

The case studies cited here show that a valuation study is much more than attaching numbers to a stream of benefits flowing from a protected area. The valuation process can provide the protected area manager with an array of funding options, help to identify potential threats to the protected area, and lead to a justification for additional funding from existing sources.

Identifying alternative funding sources is an increasingly important topic in these times of fiscal austerity. The study of Borivli National Park (2.6) reveals that local businessmen in Bombay may be one approachable group for the protected area manager, as they attach unexpectedly high values to the protected area. Of course, actually capturing the values that are identified in the study is also important. The Pilanesberg study (2.8) is particularly interesting in that it results in a transfer of money from local resorts to the protected area to cover costs for introducing lion. Identifying and capturing alternative sources of funding can serve to secure the long-term existence of the protected area and its biodiversity, as a broad funding base is likely to be more stable than a narrow one.

A protected area may have been established without consultation of local groups or stakeholders, who may stand to lose their land or livelihood. The valuation process can help managers identify the groups which suffer as a result of the presence of the protected area and, perhaps, identify ways of altering management practices to ensure that the groups derive some benefits. The establishment of Mantadia National Park in Madagascar (2.3) is an example of local people bearing significant costs because of a protected area, and therefore being a potential threat to it. Though the authors of this study recommend that local people become involved in the planning of the protected area, they do not exploit the valuation tool by identifying possible benefits that local people could derive. Lucy Emerton's study (2.2), on the other hand, gives a detailed account of many of the benefits that local people in Kenya can derive from a protected area and offers an innovative method of measuring the value of those benefits.

Perhaps the most common reason for embarking on a valuation study is that the results can be used to justify additional funding for the protected area. Howard's study of the Ugandan protected areas system (2.1) stands out in this category because of its detailed analysis of the flow of funding and benefits. His conclusion that Uganda is actually subsidising carbon sequestration for the international community is persuasive and could provide a platform for Uganda to approach international donor agencies for more money. Also, Howard's study should be commended for its exploration of the various means of capturing this international funding.

Valuation is a developing tool and, as is evident from the studies in Part II, there are many ways to approach a valuation study. The reason for conducting the study, the audience which the study addresses, the nature of the protected area, the time limits of 
the study, and the methods used for collecting the data will all be specific to the study. Table 1 below outlines how each of the studies here measure up to these tasks.

Table 1. Summary of the case studies

\begin{tabular}{|c|c|c|c|c|c|c|c|c|c|}
\hline & 1 & 2 & 3 & 4 & 5 & 6 & 7 & 8 & 9 \\
\hline Audience definition & $\mathrm{x}$ & $\mathrm{x}$ & & $\mathrm{xx}$ & $\mathrm{x}$ & $\mathrm{x}$ & $\mathrm{x}$ & $\mathrm{xx}$ & $\mathrm{xx}$ \\
\hline End use definition & $\mathrm{x}$ & $\mathrm{x}$ & $\mathrm{x}$ & $\mathrm{x}$ & & $\mathrm{x}$ & $\mathrm{x}$ & $\mathrm{x}$ & $\mathrm{x}$ \\
\hline Scope & $\mathrm{x}$ & $\mathrm{x}$ & $x x$ & $\mathrm{x}$ & & $\mathrm{x}$ & $\mathrm{xx}$ & $\mathrm{x}$ & $\mathrm{x}$ \\
\hline Limits & $\mathrm{x}$ & & $\mathrm{xx}$ & & & & & & \\
\hline \multicolumn{10}{|l|}{ Techniques } \\
\hline - contingent valuation & & & & & & $\mathrm{x}$ & & & \\
\hline \multicolumn{10}{|l|}{ - hedonic pricing } \\
\hline \multicolumn{10}{|l|}{ - travel cost method } \\
\hline - change in productivity & & & & $\mathrm{x}$ & & & & & \\
\hline - loss of earnings & & & $\mathrm{x}$ & $\mathrm{x}$ & & & & & \\
\hline - cost benefit analysis & & & & & & & & $\mathrm{x}$ & $\mathrm{x}$ \\
\hline - opportunity cost & $\mathrm{x}$ & & & $\mathrm{x}$ & & & $\mathrm{x}$ & & \\
\hline - other tools & & $\mathrm{x}$ & $\mathrm{x}$ & & & & $\mathrm{x}$ & $\mathrm{x}$ & \\
\hline Policy outcome & $\mathrm{x}$ & $\mathrm{x}$ & & $\mathrm{x}$ & $\mathrm{x}$ & $\mathrm{x}$ & $\mathrm{x}$ & $\mathrm{x}$ & $\mathrm{xx}$ \\
\hline Means of capturing values & $x$ & & & & & & & $\mathrm{xx}$ & \\
\hline
\end{tabular}

Key

1 Opportunity costs of protected areas in Uganda

2 Contingent valuation and costless choice methods in Kenya

3 Loss of productivity and contingent valuation in Madagascar

4 Stakeholder identification for Indonesian coral reefs

5 The value of forest reconstruction to the Croatian tourism industry

6 Willingness to pay for a protected area in India

7 Opportunity costs of alternative forestry practices in Nepal

8 Using a valuation study to capture revenues in South Africa

9 Benefit cost analysis in South Africa

$\mathrm{X}$ - Issue addressed

$\mathrm{xx}$ - Issue addressed very well 
Table 1. Summary of the case studies (cont'd.)

\begin{tabular}{|c|c|c|c|c|c|c|c|}
\hline & 10 & 11 & 12 & 13 & 14 & 15 & 16 \\
\hline Audience definition & $\mathrm{x}$ & $\mathrm{x}$ & & $\mathrm{xx}$ & $\mathrm{x}$ & $\mathrm{xx}$ & \\
\hline End use definition & $\mathrm{x}$ & $\mathrm{x}$ & & $\mathrm{x}$ & & & \\
\hline Scope & & & $\mathrm{x}$ & & $\mathrm{x}$ & & $\mathrm{xx}$ \\
\hline Limits & & & $\mathrm{x}$ & & & & \\
\hline \multicolumn{8}{|l|}{ Techniques } \\
\hline \multicolumn{8}{|l|}{ - contingent valuation } \\
\hline \multicolumn{8}{|l|}{ - hedonic pricing } \\
\hline - travel cost method & & & & $\mathrm{x}$ & $\mathrm{x}$ & & \\
\hline \multicolumn{8}{|l|}{ - change in productivity } \\
\hline - loss of earnings & & & & & & & $\mathrm{x}$ \\
\hline - cost benefit analysis & $\mathrm{x}$ & $\mathrm{x}$ & & $\mathrm{x}$ & & & $\mathrm{x}$ \\
\hline - opportunity cost & & $\mathrm{xx}$ & & & & & \\
\hline - other tools & & $\mathrm{x}$ & $\mathrm{x}$ & $\mathrm{x}$ & $\mathrm{x}$ & $\mathrm{x}$ & $\mathrm{xx}$ \\
\hline Policy outcome & $\mathrm{xx}$ & $\mathrm{x}$ & & $\mathrm{x}$ & & $\mathrm{x}$ & \\
\hline Means of capturing values & & & & & & $\mathrm{x}$ & \\
\hline
\end{tabular}

Key

10 The economic contribution of key conservation areas in South Africa

11 Total economic value in Kenya

12 Financial benefits to a local economy in Australia

13 Financial benefits to a regional economy in Australia

14 The effect of environmental quality on consumer demand in Honduras

15 Local and national financial benefits from protected areas in Belize

16 The opportunity cost of a Fijian mangrove

$x-\quad$ Issue addressed

$\mathrm{xx}$ - Issue addressed very well

It is our hope that as people use this guide and as more economic valuation studies are conducted, these case summaries will be updated and amended to reflect this experience. The developing nature of the valuation tool requires a dynamic and ever evolving document. Further to this end, IUCN will house the background materials for these case studies and others which are collected over time on the Internet site, $<$ http://economic.iucn.org $>$, email<economics@indaba.iucn.org> $>$. This electronic filing system will provide a growing source of information on economic valuation for protected area managers and practising economists alike. 


\section{Case studies}

This section contains case studies demonstrating a number of approaches to the economic valuation of protected areas.

\subsection{Opportunity costs of protected areas in Uganda}

Peter Howard (1995) assesses the overall benefits and costs associated with Uganda's protected area system so as to determine the net benefit to society of maintaining them. The study identifies a host of values attributable to protected areas and the array of measures which can be used in valuation. It also measures the benefits derived from direct use of marketed and non-marketed products, indirect uses and non-use values, and compares these to the costs of management and opportunity costs. A benefit-cost framework is used to compare the financial net benefit to the economic net benefit, reflected in social benefits and social costs.

Howard's study looks at the costs and benefits for three categories of protected areas: National Parks, Game Reserves and Forest Reserves. He selects three survey areas representing different forest ecosystem types, including tropical forest, savannah woodland and natural high forest mixed with grasslands.

Calculating the benefits derived from direct use of marketed products, Howard uses data on revenues from concessions, protected area and gate receipts, permits and licences, zoo entrance fees, softwood plantations, and other revenues from forest department licences for goods, such as timber, charcoal and building poles. The income from these sources is \$1 million for 1993-94 (reflecting a financial year in Uganda).

To estimate the benefits derived from the direct use of non-marketed products, Howard surveys six local villages near a representative sample of the protected areas in Uganda. In the study, 84 household heads are interviewed about their resource use and data are collected about the quantities taken, the values of each product, time involved and the local market values. From this, the mean quantities and values of firewood, poles, timber, charcoal, thatch, hunting, granary materials, food and water are calculated. The values which households attribute to the protected areas depended on their distance from the protected area. The mean annual value for protected area products for households living within $1.5 \mathrm{~km}$ of the boundary is determined to be $\$ 82$ per year. For households living 1.6-2.5km away, the value is only $\$ 36$ per year. As an alternative means of calculating this local use value, estimates are derived from the local market prices of these resources (with the exception of charcoal and timber), which range from $\$ 30$ to $\$ 136$ per household per year. On the basis of these field estimates, Howard arrives at a national figure of $\$ 33$ million annually. While there are significant benefits to households living adjacent to protected areas, there are also large 
costs suffered due to crop and livestock losses. The study determines that the annual household cost associated with these losses amounts to $\$ 135$ per year.

The indirect uses considered in Howard's study include watershed protection, carbon sequestration and potential influence on the local climate. Howard derives an estimate for the value of watershed protection benefits as a portion of the value of fish catch and arrives at a figure of $\$ 13.8$ million annually. He estimates carbon sequestration values in two ways. Based on figures of the damage that would be done if the land were converted and carbon released in the atmosphere, the value of Uganda's protected areas as a carbon sink is estimated at $\$ 245$ million, which amounts to a $\$ 17.4$ million annual cash flow if discounted at $5 \%$ over 25 years. Based on the estimated cost of replacing Uganda's carbon sink functions through an afforestation scheme, the value of the protected areas is estimated at $\$ 20.3$ million annually.

Biodiversity values are the only option and existence values measured in the study. Based on a value of $\$ 0.4$ per hectare per annum for the pharmaceutical value of rainforest land, and a $\$ 0.2$ option value per hectare per annum figure for savannah and wetland systems, Uganda's annual option value for the pharmaceutical industry is calculated as $\$ 788,000$. Additionally, the option value of Uganda's wild coffee genetic material is estimated to be worth an annual $\$ 1.5$ million.

On the cost side of the equation, management costs include capital development and recurrent expenditures (such as salaries) estimated at \$14.6 million. Howard breaks these costs down and identifies the funding sources. Of particular importance is the $\$ 6.2$ million coming from international donors for site-specific protected area management and $\$ 4.5$ million from donors for institutional support.

The opportunity costs measured in this study include benefits foregone due to the exclusion of human settlement, cultivation and pastoralism. These are measured in terms of expected net returns from conversion to land-use patterns similar to those in nearby areas. This part of the analysis uses the following steps:

1. assessment of the land area under cultivation in each district;

2. assessment of the land area under protection in each district;

3. assessment of the land area available for livestock in each district;

4. estimation of land values under cultivation;

5. estimation of land values under livestock; and

6. calculation of the potential value of protected area land under agro-pastoral development.

This results in an estimated opportunity cost from land that could have potentially been under cultivation or available for livestock production amounting to $\$ 110$ million per year.

Howard then combines these values to arrive at the total economic value of Uganda's protected areas. The net financial benefit to Uganda of the protected areas combines (in millions) total revenues (\$1) and donor contributions (\$10.7) and subtracts from these 
the government capital development expenditures $(\$ 1.1)$, the government recurrent expenditures $(\$ 1.2)$, and the national protected area revenues reinvested $(\$ 0.9)$ to arrive at a net financial benefit to Uganda of $\$ 8.5$ million which represents a net present value of $\$ 120.6$ million or $\$ 37.20$ per ha per annum (using a 5\% discount rate over 25 years).

The calculation of the value of Uganda's protected areas from an economic point of view, which takes into account non-marketed benefits and non-marketed costs, results in a very different sum. In this case, the non-marketed benefits include (in millions) timber values $(\$ 40)$, tourism revenues $(\$ 16.3)$, potential game utilisation $(\$ 0.7)$, community use (\$33), watershed benefits $(\$ 13.8)$, carbon sequestration $(\$ 17.4)$, and biodiversity option value $(\$ 2.3)$. These total $\$ 123.5$ million. The non-marketed costs include financial costs to Uganda, which are identical to the financial costs listed under the financial net benefit case above (\$3.1), donor contributions (\$10.7), crop and stock losses $(\$ 75.5)$, and opportunity costs $(\$ 110.6)$ totalling to $\$ 199.9$ million. Thus, the economic perspective of the protected areas of Uganda indicate a net loss of $\$ 76.4$ million annually - representing a net present value of $\$-1,077.60$ million per year, or $\$-332.4$ per ha per year (at a 5\% discount rate over 25 years).

From this analysis, Howard then suggests that Ugandan protected area managers should find ways of increasing the direct revenues and social benefits from the protected area network, while seeking to reduce the management costs incurred. The national government should look at ways of increasing investment in its protected areas and reducing the demands on protected areas that are resulting from population growth.

Comparing the carbon sequestration benefits attributable to Uganda's protected areas and the current level of donor contributions to protected areas, Howard determines that Uganda is effectively subsidising the clean-up of atmospheric pollution from industrialised nations. Therefore he recommends that donors increase their level of support for protected area management and additional funding made available through mechanisms such as the GEF.

This example highlights the difference between financial and economic assessment in benefit-cost analysis. The net values for national considerations are strictly financial and the result differs substantially from the economic values, calculated at the international level. This is because the economic values reflect social benefits and costs. Many of these costs are not reflected in the financial analysis, such as the substantial estimate of opportunity costs, and some of the benefits in the financial analysis are actually interpreted as costs under the economic calculation.

Equally important is the array of policy suggestions that come out of such a study. The values have highlighted several management and financing measures which can be taken at many levels - from protected area managers to international donors - to improve the situation of Uganda's protected areas. 


\subsection{Contingent valuation and costless choice methods in Kenya}

This study, conducted by Lucy Emerton of the African Wildlife Foundation (1996), provides a closer look at the process of eliciting people's non-market values for protected areas. The study was conducted to identify how and why local people use forests around the Aberdares in Kenya, so as to guide protected area managers towards a management system which integrates meeting local people's needs with conservation efforts.

The group conducting the study has to overcome a general unwillingness to reveal values of forest products, because many of the villagers' uses are considered illegal under the current management regime. By showing pictures of different types of forest use, the survey team provides a feasible alternative to direct questioning, which proves capable of eliciting values - though occasionally there is a problem of misinterpretation of the pictures. The forest uses measured include fuelwood, grazing, charcoal, building materials, honey, medicines, wild foods, hunting, and timber.

The group finds that cash measures have little relevance in the region. It is therefore necessary to find an item which has local value and can be translated into a monetary amount - such as a radio, a bicycle, or a milk cow. Cards represent the various forest uses and villagers are asked to allocate counters (seeds or stones) to each use in order to rank the value of each activity and the monetary item. For instance, if five counters are allocated to a radio (worth, say, \$20), ten counters allocated to fuelwood, and 13 counters to grazing, then the value of fuelwood is two radios $(\$ 40)$ and the value of grazing 2.6 radios $(\$ 52)$. From this the number of counters allocated to each card is translated into a wealth item equivalent, then to a cash amount, which is discounted to arrive at an annual forest use value. The average annual forest value comes to 18,408 KSH in 1996 (or \$306) per household.

The valuations arrived at through this study reveal the costs imposed on local communities by cutting off legal access to forest products in the protected areas. Additionally, these values indicate the high value of use for local livelihoods, which in turn can lead to ways of incorporating the community in management practices. Such a study can provide a useful means of turning threats to a protected area into assets - by partnering with villagers interested in the sustainable use of forest resources.

\subsection{Loss of productivity and contingent valuation in Madagascar}

Priya Shyamsundar and Randall Kramer's study of households in the vicinity of Mantadia National Park in Madagascar (Shyamsundar and Kramer, 1997) reveals some of the motives behind local resistance towards conservation efforts. The study uses cash flow and risk analysis to determine the magnitude of costs borne by local residents, due to lost access to land with the establishment of the protected area.

Cash flow analysis is an accounting tool which evaluates the monetary value of a flow of resources to a group of people. This study estimates the net present value of costs impacting three groups neighbouring the protected area. These costs are based on benefits foregone from agriculture and forest products, which are adjusted for labour 
and capital costs. Risk analysis looks at a range of outcomes, such as low or high deforestation rates or low or high commodity prices, and predicts the likelihood of each outcome. Introducing risk allows for a consideration of the possible variation in factors which affect the net present value estimate. It is used to find mean net present values (NPV) of the costs.

Welfare implications are measured in terms of estimating the amount of land lost to households, reflected in reduced household production, which affects household income and consumption. A household survey is conducted to obtain information on land-use patterns, agricultural yields, forest outputs, forest product processing, and labour use. Interviews reveal market and price information related to the local subsistence economy.

The study finds that households bear an average cost of $\$ 49$ annually, which is approximately $18 \%$ of total gross household income in 1991 . While the average NPV cost (calculated on a 20 year basis) is $\$ 419$, NPV costs vary from $\$ 240$ (group 1) and $\$ 427$ (group 2) to $\$ 564$ (group 3), indicating that cost estimates for villages to the south-west of the protected area are much higher than those estimated for other villages.

Shyamsundar and Kramer do not provide a full accounting of the benefits and costs of conservation, since amenity, non-use and environmental values associated with forested protected area land are not measured. The authors conclude that such an exercise is valuable for its insight into relative differences of use by local residents and the different welfare impacts upon protected area-adjacent communities. They argue that the relative magnitude of the costs may be more important for policy decisions than the absolute value of the costs. The aggregate NPV of costs for a total population of 3,403 came to $\$ 305,590$. This figure represents the value of benefits foregone to villagers due to the presence of the protected area.

This study can help managers understand and manage for local needs. Clearly, local residents stand to lose economically from the establishment of a protected area in their neighbourhood. Hence villagers need to be actively involved in the planning of protected areas if conservation efforts are to succeed.

\subsection{Stakeholder identification for Indonesian coral reefs}

Though not a valuation study of a protected area, but rather of a threatened ecosystem, this study of the values and forces behind the destruction of Indonesian coral reefs was conducted to recommend management responses. It reveals the importance of discovering not only what values exist but also who holds those values. In this study, Herman Cesar et al. (1997) attribute the deterioration of Indonesia's coral reefs to five causes: poison fishing, blast fishing, coral mining, sedimentation and pollution, and overfishing.

The study looks at the forces driving each of these destructive activities, the costs involved, and the distribution of the benefits and costs. It relies on observable data such as the value of the declining fish catch or hotel expenditures on reversing the process of 
beach erosion. On the basis of these data, the study estimates the losses attributable to each threat in terms of fisheries, coastal protection, tourism and other losses, such as food security and biodiversity values. The estimated total net loss to society from poison fishing ranges from $\$ 43,000$ to $\$ 476,000$; from blast fishing, $\$ 98,000$ $\$ 761,000$; from coral mining, $\$ 176,000-\$ 903,000$; from logging sediment, $\$ 273,000$; and from overfishing, $\$ 109,000$. This compares to net benefits for individuals/ stakeholders derived from poison fishing of $\$ 33,000$; from blast fishing, $\$ 15,000$; from coral mining, $\$ 121,000$; from logging sediment, $\$ 98,000$; and from overfishing, $\$ 39,000$.

It is evident that the non-marketed costs of these activities greatly outweigh the benefits, so why do the threats exist in the first place? The authors answer this question by looking at the size of the stake per person and at the location of the individual causing the threat. They find that for poison fishing and logging, the private benefits per stakeholder are significant - ranging from $\$ 2$ million per logging company to $\$ 0.4$ million per fishing boat. They also find that large scale poison fishing operations are conducted by captains and crews from outside the local area, as is frequently the case with logging-induced sedimentation. Overfishing, though, may arise from local or distant sources.

The location of beneficiaries and size of their economic stake are important factors in determining appropriate management alternatives to the status quo. For instance, small threats from insider or outsider groups may be dealt with through community-based management techniques. In the case of overfishing, alternative income generation activities, regulations and the establishment of co-operatives may sufficiently address the threat. The authors suggest that when large threats derive from outside - such as poison fishing - these are best addressed through national action as it may require the involvement of the navy or police in large operations. Integrated coastal zone management is recommended as a tool for dealing with large internal threats as it is capable of dealing with multiple threats in an integrated manner. New legislation to transfer user rights to reef resources to local communities, or to sanction a return to the system of traditional rights (e.g. the 'sasi' system), would also offer solutions to current destructive behaviour.

The authors suggest that current implementation efforts of marine protected areas have so far been ineffective, due to poor management capacity. They assert that outside technical support or private sector interest, teamed with a stakeholder approach, may improve these results. They emphasise the importance of capturing revenues to compensate the destructive users for benefits foregone.

\subsection{The value of forest reconstruction to the Croatian tourism industry}

An economic analysis of a proposed Coastal Forest Reconstruction and Protection Project in the Republic of Croatia, Stefano Pagiola's (1996) study reveals the significance of environmental amenities - such as forests - to the tourism industry. Though not a study of a specific protected area, it is relevant to this guide because its lessons can be readily applied to protected areas. 
The study is focused on the war-torn coastal zone forests of Croatia, which are particularly important for the tourism industry. The primary benefit of the forests is considered to be their contribution to the landscape. Additional values included in the study are benefits from wood production, hunting, and - where appropriate - watershed functions.

14 sites have been proposed for a reforestation project, so the economic assessment is conducted for these sites. Estimates for the landscape value of reforestation are based on the tourists' willingness to pay for the forested landscape (derived from previous contingent valuation studies) estimated to be $\$ 1.50$ per tourist per day. Benefits from each site are then determined from the number of hotel beds which would benefit from the reforestation (based on the area visible from each site). The results are adjusted for site-specific factors - such as whether they will provide benefits to tourists driving through the region, but not occupying hotel beds, or sites which suffer from negative features (such as a mine) and would therefore be less likely to obtain the average willingness to pay for a forested landscape.

Hunting values are measured in terms of additional permits sold to foreign hunters. Wood production is based on harvest rates for pulpwood or saw-logs, and assumed stumpage fees of $\$ 10 / \mathrm{m} 3$ and $\$ 30 / \mathrm{m} 3$ respectively. Where watershed values are relevant, benefits are calculated on the basis of cost per hectare to avoid the damage caused by deforestation.

The costs of the project at each site are measured in both financial and economic terms. These are based on discussions with those implementing the project. The major difference in the financial and economic valuations results from the difference in labour costs. The financial measurement uses a labour cost of $\$ 36 /$ day where the economic analysis uses a cost of $\$ 23 /$ day - which adjusts for taxes and other transfers.

Based on these figures, Pagiola determines that the landscape considerations are paramount and by themselves justify restoration at all of the sites where restoration has a positive rate of return. (At these same sites, the total of the other three benefits would not be enough to justify reforestation). Relaxing the assumptions (about willingness to pay and the recovery of tourism) does not change the results.

Though 11 of the sites in this study are judged on a benefit-cost basis, the author argues that three of them should be judged on a cost-effectiveness basis because they are inside a national park. Cost-effectiveness criteria are more relaxed than benefit-cost criteria, thereby enabling the decision-maker to account for the fact that the primary function of forests within the park is their contribution to the park's ecosystem rather than to the tourism industry.

This study demonstrates how valuation can be used as a tool for aiding decisions at a project level. Economic benefits of environmental amenities such as forests can and should be included in the benefit-cost analysis of projects. At times these values may prove to be the deciding factor in the analysis - such is the case with the landscape values of forests in the coastal zones of Croatia. 


\subsection{Willingness to pay for a protected area in India}

Though largely an academic exercise in contingent valuation, Hadker's study (1997) provides some interesting insights into the practice of contingent valuation in a developing country. The focus of the study is Bombay (now Mumbai) residents' willingness to pay for maintenance of Borivli National Park, which is located within the city limits of Bombay. The study interviews nearly 500 residents from around the city and from a variety of socio-economic backgrounds.

Interview material includes a brochure which informed the respondent about the protected area, including a description of the valuable flora and fauna and the management problems that the protected area currently faces. Respondents are assured confidentiality and are given the prospect of making monthly payments over the next five years. The first section of the interview is dedicated to obtaining information about the respondent's social, economic and demographic characteristics: their age, gender, occupation, education level, residential area, family size and income level.

The second section of the interview tries to categorise the respondent as pro-conservation, pro-development or in the middle. The third section involves the presentation of the brochures and information about the protected area. Respondents are then presented with two scenarios - one where present detrimental trends continue, and another where a management plan is put in place to halt these trends. In the fourth section respondents are given an 'opening bid', representing their contribution for the implementation of such a management plan.

After explaining that acceptance of the bid would mean they would be likely to forego alternate investments - in other environmental causes or goods or services respondents are asked to accept the bid, reject the bid, or offer no response. Respondents accepting the bid are then asked the maximum they would pay. Additionally, respondents are asked if they would like to volunteer in the protected area. This question is intended to discover the willingness to pay of people who could not afford a monetary bid. The study finds that time constraints limit respondent's ability to volunteer.

In designing the survey, the team attempts to:

1. make the objectives of the interview clear;

2. enable interviewers to record as many of the preferences respondents were expressing as possible;

3. account for, and manage, the numerous biases relating to a contingent valuation study; and

4. define the scenario as realistically as possible.

The study finds that income, visitation rate to the site, membership in an environmental organisation and preferences for environment-related activities are significant in identifying those respondents with higher values for the protected area. This last factor - the "green" factor - is explained by economists by embedding, where a person's response to a valuation is affected by their underlying value system. 
Interestingly, businessmen are willing to pay significantly more than other professionals. The study suggests that this has important policy implications as this group may be able to finance environmental improvements. Indeed, it would seem logical for the protected area manager reviewing this study to pursue this avenue of funding.

Additionally, the study arrives at a willingness to pay of 7.5 Rupees (equal to $\$ 0.23$ in 1995) per month per household. This amounts to a total present value of 1033 million Rupees (or $\$ 31.6$ million). The authors suggest that this number could be used to influence policy decisions as the protected area currently runs on a budget of 17 million Rupees (or $\$ 520,200)$.

This study is also interesting for its treatment of a number of biases which it accepts may introduce an element of uncertainty into the valuation study. When an adjustment is made for this uncertainty, the estimated mean value for willingness to pay drops from 27.75 Rupees $(\$ 0.85)$ per month to 7.5 Rupees $(\$ 0.23)$ per month. Willingness to pay is also broken down into groups of people who are defined as pragmatic (12.81 Rupees or $\$ 0.39$ ), green (with a very high level of 40.85 Rupees or \$1.25) and development-oriented (10 Rupees or \$0.31).

Though the study is largely dedicated to the development of contingent valuation methodology for the case of developing countries, it arrives at some interesting insights for policy and management avenues, such as the idea of approaching businessmen for funding. Some aspects of the study, such as the idea of volunteering in lieu of a monetary payment, provide possible alternatives to problems which are more likely to occur in developing countries.

\subsection{Opportunity costs of alternative forestry practices in Nepal}

Though this too is not strictly a protected area case study, Katherine Houghton and Robert Mendelsohn's economic analysis of multiple-use forestry in Nepal (1997) demonstrates how valuation information can feed into decisions about alternative management practices. This study compares the contribution to net income of five different forest types to non-irrigated agriculture.

Forested land in Nepal has been the issue of some intense property rights conflicts between the Nepalese Government and villagers. The government has traditionally used forested land for timber or conversion to farmland. Villagers rely on forests for fuelwood and fodder. In 1957, the government nationalised all forests and banned villagers from them. However, in 1978 national legislation on community forestry was passed that allowed for the handing over of forest management rights for a large portion of the forests in the Middle Hills. Thus, once a management plan is agreed between local communities and a forest officer, forest use by villagers is no longer considered illegal. Yet, even after the handover of community forests, the government has not fully acknowledged the value of non-timber forest products and thus has, in the view of the authors, underestimated the importance of multiple-use forestry. 
The authors measure the value of three products - timber, fuelwood and fodder over the life of five types of stands (chir-pine, old-growth sal, seedling sal, oak and chir-pine mix, and rianj oak). The quantity of a particular product varies over the course of the life of a tree. For example, fodder in the form of grass is available from the first year of a plantation, while fodder in the form of leaves is available from the fifth year on. Fuelwood from branches is available from the seventh year on and from the bole (tree trunk) from the 15th year on. Timber is available from the 15th year on.

Firewood and fodder prices and harvesting costs (measured in time spent collecting) are obtained through interviews. Timber prices are fixed by the government and therefore do not necessarily reflect the true market price. Instead the authors use fuelwood prices as a minimum measure of timber products - as timber producers would sell their boles for fuelwood, if fuelwood prices were higher than timber prices.

Combining the quantity, price and collection cost data, the study concludes that the net value of branches is low - largely because of the time involved in collecting them. The high price of grass makes grass production one of the most important sources of revenue. Fodder production in general accounts for $40-55 \%$ of the net value of broadleaf forests but only $22 \%$ of the net value of evergreen forests. Bole provides between $42-54 \%$ of the net value for broadleaf forests and $71 \%$ of the value for evergreen forests. Overall, broadleaf forests are found to have higher net present values - ranging from $\$ 2,732$ to $\$ 3,616$ per ha - than the evergreen forests - valued at $\$ 2,167$ per ha.

The authors conclude that landowners can best use their forests by taking advantage of fodder, fuelwood and timber products. Comparing the forest values to agricultural values, the authors further determine that forests generate more than $10 \%$ higher values per ha than agriculture (or a net present value for non-irrigated agriculture of $\$ 3,140$, which includes maize, millet, wheat, crop residue and terrace grass). Thus, multiple-use forestry management practices provide the most efficient use of forests in Nepal.

\subsection{Using a valuation study to capture revenues in South Africa}

The importance of identifying the groups of people who obtain the benefits as well as those who pay the costs associated with those benefits is brought out in an economic study by Deborah Vorhies and Frank Vorhies (1993). The study was commissioned by a protected area and wildlife management board to inform a management decision to introduce lion into Pilanesberg Protected area in South Africa. By tracing both the benefits and costs of introducing lion, the authors identify the potential ecological, social, economic and political impacts related to lion introduction.

On the benefit side of the equation, the authors determine that the primary benefit from the introduction of lion would come from increased tourism expenditures in the protected area and in the neighbouring resorts. The study measures these benefits through increases in gate revenues, camp revenues, photo safaris, hunting safaris and resort revenues. 
The authors divide the costs of introducing lion into capital and operational costs. Capital costs include the purchase of the lions, sterilisation, boma facilities (confined areas for the lions when they are first moved to the protected area), monitoring equipment, fencing and so on. Operating costs include salary for a monitoring officer, monitoring costs, maintenance, insurance, food for the lions and so forth. Worst, likely and best scenarios for each of the benefits and costs are given to account for various projected changes.

Based on these benefits and costs, the authors conclude that the protected area itself would lose between $\$ 63,000$ and $\$ 670,000$ with the introduction of lion. On the other hand, the region would earn between $\$ 5,300,000$ and $\$ 12,000,000$. This second set of 'regional' numbers reflects the significant benefits to the tourism industry from the introduction of lion into the protected area. Based on this study neighbouring tourist resorts agreed to cover the costs to the protected area of the lion introduction programme.

\subsection{Benefit cost analysis in South Africa}

In his study of Kruger National Park in South Africa, administered by the South African National Parks Board, Mike 't Sas-Rolfes (1997) examines the flow of costs and benefits, identifies the groups who attain the benefits and bear the costs, determines the threat that arises out of this allocation of costs and benefits, and recommends alternative policies and management practices and policy roads.

The study determines that protected area staff, visitors, scientists and poachers receive benefits under the current management style in the form of employment, below market visitation fees, access to an 'outdoor laboratory' and income from harvesting resources. Additionally the protected area provides values in the form of education, environmental services, and option and existence values.

Costs are accrued by South African taxpayers, local people, the South African public and consumers of natural products. The taxpayer contributes to the park's operations. Local people are subjected to raids by wild animals such as elephants, lions and hyenas. The local public therefore bears the costs from owning an asset which they do not benefit from. Consumers of natural products bear a cost because they are denied access to them despite their willingness to pay market values. Additionally, the local public may hold a negative existence value for the protected area because they view other uses of the land as more beneficial.

The distribution of these benefits and costs demonstrates the inequitable nature of current protected area management practices. Additionally, the study shows that Kruger National Park's performance is inefficient because many of the opportunity costs exposed in the 'costs' section could be eliminated or converted to benefits without seriously compromising the existing benefits. In other words, it is possible to make some people better off without making anyone else worse off.

The study concludes with a series of recommendations for the South African National Parks Board, including a suggestion that the Board:

1. diversify Kruger National Park operations - increasing the range of revenue producing activities; 
2. democratise the park's management operations through a devolution of property rights to local people or through the development of more participatory systems of democracy; and

3. commercialise the management of the park.

This last concept, commercialising the management of the protected area, is particularly interesting for the purposes of this guide. Commercialisation, as ' $t$ Sas-Rolfes refers to it, includes any changes to the management regime that lead to greater use of business principles. 't Sas-Rolfes argues that commercialisation will lead to greater efficiency in the running of the protected area which will in turn result in improved benefits to taxpayers since they get better value for their money. This occurs because state subsidies are cut and the financial viability of the protected areas system is strengthened. As a result, funds are released for non-commercial conservation activities. Together these developments help to secure the long term financial viability of the Kruger National Park's management.

't Sas-Rolfes recommends that the National Parks Board establish strong property rights, market pricing and a competitive environment in order to institute a more commercially viable operation. These steps will provide managers and other stakeholders with incentives to improve their performance and that of the National Park as a whole.

\subsection{The economic contribution of key conservation areas in South Africa}

Geert Creemers, Louis Liebenberg and Peter Massyn (1995) examine the economic contribution of key conservation areas such as St. Lucia in South Africa. The values measured in this study are based on the financial benefits the protected areas bring to the South African economy.

The study argues that certain protected areas in South Africa - such as Kruger National Park, the Cape Peninsula, and possibly St. Lucia - are instrumental in attracting tourists to South Africa. Therefore, the authors believe, the value of the tourists' financial contribution to the South African economy should be based on the total value spent in the country by tourists who have chosen South Africa because of the particular protected area(s) which have attracted them.

The authors argue that St. Lucia's high biodiversity, its status as a Wetland of International Importance under the Ramsar Convention, its application for status as a World Heritage Site, and the fact that it is home to the 'big five' game species ranks it among the key protected areas for tourism.

The study was produced to refute an estimate completed by an Environmental Impact Assessment (EIA) team for a proposed mining project in St. Lucia. The EIA places a value of foregone tourism benefits (due to mining) at between R30 and 70 million. The authors argue that this value, which assumes that visitors will select alternate destinations in South Africa, understates the potential impact of the mining 
operations. Working from an alternate set of assumptions (that the presence of the mine could preclude overseas marketing of the park), the authors conclude that foregone revenue to national tourism would be R300 million per annum. This figure, when projected over 28 years (un-discounted) amounts to a loss of R8000 million, which rivals the expected revenue for mining.

Based on these results, the authors argue that the mining proposal should be rejected as it jeopardises the site's application for World Heritage status, and is not in keeping with South Africa's obligations under the Ramsar Convention and the CBD.

The study was presented at a national workshop attended by the Ministers of Economic Affairs of the province and subsequently had a major impact on the mining development plans. The mining application was rejected on the basis that conservation could bring economic benefits while being environmentally sustainable. Incidentally, the mining project's EIA was the largest ever undertaken in Africa, costing about R10 million. This economic valuation study was done without a budget and took 10 days to complete. This emphasises how tailoring the study to the needs of the audience can minimise the costs and maximise the effectiveness of the study.

\subsection{Total economic value in Kenya}

M. Norton Griffiths (1994) uses a total economic value framework to determine what costs and benefits are associated with Kenyan protected areas and where those costs and benefits accrue - nationally or globally. The study arrives at some interesting conclusions in that Griffiths determines that the Kenyan government is subsidising global use and non-use values for the protected areas.

By measuring the tourism, forestry, watershed, biodiversity and carbon sequestration benefits and the opportunity costs of Kenyan protected areas, Griffiths determines that Kenya bears an annual net cost of US $\$ 2.8$ billion. This is largely because of the significant opportunity costs as measured in terms of the value of protected area land if it were converted to agricultural or other uses. On the other hand, the global benefits of Kenya maintaining the protected areas amount to a significant $\$ 11$ billion. Thus, it is in the global interest for Kenya to maintain its protected areas.

The obvious policy implication is for the global community to compensate Kenya for maintaining their protected areas and foregoing the development benefits. The GEF is one possible mechanism for making such a payment. The GEF pays the incremental costs for projects undertaken by a nation to preserve biodiversity. The incremental costs are those additional costs that the nation would accrue by altering a project in such a way that it serves the global environment.

But, as Griffiths rightly points out, Kenya's situation was not considered when the rules to the GEF were drawn up. There is no single 'project' in Kenya for the GEF to fund, nor are there incremental costs.

Griffiths suggests that Kenya could propose a project to develop a portion of their conservation estate. The global community should then be willing to pay Kenya not to 
pursue the project. He terms this 'environmental blackmail' and suggests that any country pursuing such a strategy for acquiring global funding for its protected areas would 'come under intense pressure'. An alternative could be to establish a trust fund which would provide Kenya with annual derivatives for maintaining their protected areas.

\subsection{Financial benefits to a local economy in Australia}

As part of a larger book on the Economic Evaluation of National Protected Areas, the Warrumbungles study (Ulph and Reynolds, 1981) measures the value of Warrumbungles National Park to the local economy. The Warrumbungles National Park is located in New South Wales, Australia.

This study surveys regional tourist expenditures; collates expenditure data on protected area operations; surveys regional employment and recreation-related industries resulting from the protected area; and traces the effect of this employment as it filters through the regional economy. The study then applies employment and income multipliers and finds that the protected area brings $\$ 8.5$ million annually into the local economy. Protected area costs are determined to be in the order of $\$ 3.95$ to $\$ 5.44$ per visitor-day. Thus the study concludes that the Warrumbungles National Park contributed $\$ 500,000$ and 39 jobs to the economy of the local area in 1978.

The Warrumbungles study focuses on the financial value contributed by the tourism and recreation sectors, and the government expenditure paid into the region. The report then checks to ensure that the costs of protected area operations were less than the revenue generated by the protected area.

The strongest merit of the Warrumbungles study is the elegant means by which it explains the key features of an economic assessment. Though the book was written in 1984 , it provides the reader with a useful introduction to economic valuation issues. It also provides an explanation of welfare analysis. The study's results, methodology and practice examples are easy to follow.

\subsection{Financial benefits to a regional economy in Australia}

The Grampians National Park study (Read-Sturgess, 1994) was completed in 1994 on behalf of the State Government of Victoria, Australia. The study assesses the contribution of the Grampians National Park to the regional economy and calculated consumer surplus benefits from the area.

The study identifies tourism/recreation, honey production and water production as economic and financial values derived from the Grampians region. Mining and forestry occurred in the past but are no longer practised. The site, and hence the Grampians region, is the beneficiary of expenditure by the State government. Apart from mention of the previous activities, no opportunity costs are given. It is assumed that the opportunity cost of establishing the Grampians National Park area is zero. 
In completing the study, the authors first identify the relevant region around Grampians National Park which is defined by direct expenditures of visitors to the protected area, and the associated level of employment. From these expenditures and the related jobs, the study estimates the multiplier effect of direct expenditure in the Grampians region on the economy of Victoria as a whole.

Travel cost methods are used to estimate tourist expenditure (calculated by using total trip costs) and on-site costs (estimated using a weighted average of three visitor classes). The authors note that the expenditures incurred by the protected area authority and other agencies within the region would otherwise have been avoided if the Grampians National Park had not been established.

The Grampians National Park has 68 sites for bee hives. These produce honey that raises about $A \$ 156,000$ (US\$120,000) per year in revenue. Other benefits include building up hive strength and bee numbers, but these benefits are not quantified.

A visitor survey forms the basis for the calculation of tourist expenditure. The survey looks at accommodation, mode of travel and length of stay. The study then estimates likely expenditure on car or bus travel costs, accommodation, food and other expenses on the basis of these survey data. A major concern in this study is the allocation of transport costs, and distinguishing between different types of visitors. Visitors are classified by their point of origin, distance travelled, length of stay, mode of transport and estimated costs for different components of the visit.

Water data estimates correspond to likely water prices inferred from known water prices. However, this calculation was taken no further.

Indirect and induced financial benefits are calculated by applying a multiplier to direct expenditure in the region in order to obtain an overall assessment of the economic impact on the region. Similarly, the State multiplier is applied to the direct expenditure in the region so as to obtain a measure of the overall economic impact through indirect and induced effects.

The Grampians National Park study demonstrates the possibilities for assessment when using limited data. The absence of cost data necessitated the estimation of costs, which were then manipulated by estimated multipliers. The study also clearly outlines problems surrounding allocation of expenses for travel purposes.

\subsection{The effect of environmental quality on consumer demand in Honduras}

This study was conducted by Linwood Pendleton (1993), based at the Yale School of Forestry and Environmental Studies in the United States. His work examines the role of environmental quality in determining the frequency of diver visitations in Roatan, Honduras.

This study uses multiple regression analysis to test the hypothesis that environmental quality affects the demand for dive sites. Put simply, it sought to test whether 
environmental, topographical and time parameters determine the number of visits at dive sites.

The study recorded data from one resort that was thought to have $90 \%$ of the dive visitors for the area studied. The data recorded included:

- the number of divers;

- dive boat destination for all day dives;

- the number of divers per dive site per boat trip;

- number of visits to a dive site by dive boats; and

- time each dive occurred (morning or afternoon).

Each dive site was measured using four environmental parameters, which were indicators of reef health:

- percent of live coral cover;

- percent of algal cover;

- parrot fish abundance; and

- sturgeon fish abundance.

The presence of topographically interesting attributes such as caves and tunnels were evaluated, using 'dummy' variables for each category. At the suggestion of the dive masters, the number of houses within view of the dive site was also included.

Intuitively, it would seem reasonable to postulate that, to some degree, the environmental quality of the reef would positively correlate with the number of tourist visits. If the relationship is positive and strengthening, the implication is that one way of increasing economic benefits is to improve environmental quality.

The study concludes that the travel time to the dive site and percent of live coral cover were significant variables in the divers' choice of sites. Also significant was the presence of interesting topographical features. Aside from the percent of live coral, other indicators of coral health were not significant variables, nor was the number of houses visible at the dive site.

\subsection{Local and national financial benefits from protected areas in Belize}

Kreg Lindberg and Jeremy Enriquez (1994) conducted a study commissioned by the World Wildlife Fund in conjunction with the Belize Ministry of Tourism and Environment to examine the contribution of ecotourism to environment and development in Belize. The aim of the study is to provide information to assist planning and development efforts in Belize. 
The study focuses on benefits of tourism to protected areas, local economies and the national economy. At the protected area level, the primary focus is on financial impacts. At the local level, employment and income impacts are the primary focus.

At the protected area level, the authors judge tourism on two sets of criteria: 1) does tourism pay for itself? and 2) does it generate revenue above the level necessary to cover costs incurred to proved ecotourism opportunities? They determine that the protected area funders (government and international donors) are subsidising tourism thus not even the first set of criteria are met.

The authors suggest that the government set out general objectives for tourism (such as whether tourism should be subsidised, just pay for itself, or support protected areas). The government should then allow individual protected areas to develop site-specific policies for meeting these objectives. Additionally, revenues earned by protected areas should be returned to protected areas and the government should establish an endowment fund which enables 'popular' protected areas to cross-subsidise unpopular, but environmentally important, protected areas.

At the national and local economy level, the authors conclude that the Belizeans have not taken full advantage of tourists' values for protected areas. Their recommendations to the Ministry of Tourism and the Environment and other governmental and quasi-governmental agencies include:

1. increase training and capital availability to help Belizeans own and manage tourism businesses;

2. improve tourism promotions;

3. link tourism to other sectors in the economy;

4. improve tourism infrastructure including facilities and services; and

5. expand tourist attractions.

\subsection{The opportunity cost of a Fijian mangrove}

Padma Lal (1990) completed this study as a PhD thesis. It was subsequently published by the United Nations Development Programme (UNDP) and UNESCO. This study examines mangrove conservation and use in Fiji and analyses ecological and economic dimensions of mangrove management actions. Specifically, the study analyses the decision to carry out rice farming and sugarcane farming schemes from an economic and financial standpoint. The analysis is useful for: (a) its comparison of financial and economic costs and benefits; (b) its integration of subsistence use benefits into a benefit-cost framework; and (c) its application of incomes approach, alternative costs, and non-market transactions of use rights to measure economic costs and benefits. Additionally, the study shows how ecosystems can be used to delineate the boundary of a valuation study.

The dual analysis of financial and economic costs and benefits reveals how the scope of a valuation study can affect the results. For instance, Lal finds that the financial costs 
of farming one hectare of recovered land range from $\$ 528$ to $\$ 617$ but the economic costs of farming that same land (accounting for subsidies and family labour) range from $\$ 592$ to $\$ 761$.

The economic analysis becomes particularly relevant when Lal examines the subsistence use of mangroves. The net benefits of subsistence uses of fisheries products nearly equals the net benefits of commercial uses. For forestry products, the subsistence uses exceed the commercial uses. Clearly a straight financial analysis would miss a large portion of the picture.

Lal uses a number of techniques to measure the non-commercial benefits and costs. The incomes approach values the marginal change in fishery output as the mangrove swamp is reclaimed. Where such information is not available, a sensitivity analysis is applied using factors derived from the literature. The alternative cost method derives the waste recycling value of wetlands based on the cost of the next possible solution - a tertiary sewage treatment plant. The non-market transaction of use rights reveals an estimate of ecosystem values based on the practice of trading use rights.

The case of the non-market transactions of use rights is particularly interesting. Indigenous peoples in Fiji hold the right to use the mangroves as "traditional fishing right owners" (TRFO). In the 1960s a non-market institutional mechanism was established to provide a formal process of compensating TFROs for losses incurred from the conversion of mangroves as a result of development. The amount of compensation is determined by an independent arbitrator, though, which leads to wide variations in amounts given for compensation. Lal observes that these variations are rarely related to the ecosystem of economic parameters but rather to the political activity of the TFROs (those who are more politically active receiving more compensation).

Finally, Lal demonstrates how ecosystems can be used to define parameters of a valuation study. Mangrove ecosystems are linked terrestrial-aquatic systems which are affected by upstream land-use decisions and are at the same time important to the aquatic part of their life zone. This interrelated nature of the ecosystem highlights potential secondary impacts of developments. 


\section{Bibliography}

AUSTRALIAN DEPARTMENT OF THE ENVIRONMENT, SPORT AND TERRITORIES. (1995) Techniques to Value Environmental Resources: an Introductory Handbook. Available from <http.//kaos.erin.gov.au> Australian Government Publishing Service.

AYRES, W. and DIXON J. (1995) Economic and Ecological Benefits of Reducing Emissions of Sulfur Oxides in the Sostanj Region of Slovenia. World Bank, Washington DC, USA.

BARBIER, E., ACREMAN, M. and KNOWLER, D. (1997) Economic Valuation of Wetlands. IUCN, Cambridge, UK.

BELL, F. (1997) The Economic Valuation of Saltwater Marsh Supporting Marine Recreational Fishing in Southeastern United States. Ecological Economics 21 (1997) 243-254.

CESAR, H., LUNDIN, C.G., BETTENCOURT, S. and DIXON, J. (1997) Indonesian Coral Reefs-An Economic Analysis of a Precious but Threatened Resource. Ambio Vol. 26 No. 6 pp.345-350.

CREEMERS, G., LIEBENBERG, L. and MASSYN P. (1995) A New Perspective on the Economic Contribution of Key Conservation Areas in South Africa: A case study of St. Lucia. Presented at the St. Lucia Land Use Options Workshop 7-8 November 1995, KuaZulu, Natal.

DAVEY, A. G. (1998) National System Planning for Protected Areas. IUCN, Gland, Switzerland and Cambridge, UK.

DAVIS, D. and BANKS S. (1997) Whale Sharks in Nigaloo Marine Park: managing tourism in an Australian marine protected area. Tourism Management. Vol. 18, No. 5 , UK.

DAVIS, D. and TISDELL C. (1996) Economic Management of Recreational Scuba Diving and the Environment. Journal of Environmental Management 48, 229-248.

DE GROOT, R. (1994) "Functions and Values of Protected Areas: a comprehensive framework for assessing the benefits of protected areas to human society" In Munasinghe, M. and J. McNeely (1994) Protected Area Economics and Policy. World Bank, Washington DC, USA.

DIXON, J. (1989) Valuation of Mangroves. In Tropical Coastal Area Management. USAID, Manila, Philippines. 
DIXON, J. A. and SHERMAN, P.B. (1990) Economics of Protected Areas: A new look at benefits and costs. Island Press, Washington DC, USA.

DIXON, J., SCURA, L. and VAN'T HOF, T. (1995) Ecology and Microeconomics as 'Joint Products': the Bonaire Marine Park in the Caribbean. In Perrings, C. et al., (eds.) 1995. Biodiversity Conservation. Kluwer Academic Publishers. The Netherlands.

DRIML, S. (1997) Bringing Ecological Economics out of the Wilderness. Ecological Economics 23 pp. 145-153.

EMERTON, L. (1996) Participatory Environmental Valuation: Subsistence Forest Use Around the Aberdares, Kenya. African Wildlife Foundation, Nairobi, Kenya.

GARROD, G. and K. WILLIS. (1997) The Non-use Benefits of Enhancing Forest Biodiversity: A contingent valuation study. Ecological Economics 21 (1997) $45-61$.

HADKER, N., SHARMA, S., DAVID, A. and MURALEEDHARAN, T.R. (1997) Willingness-to-pay for Borivli National Protected area: Evidence from a Contingent Valuation. Ecological Economics 21 pp. 105-122.

HODGSON, G. and DIXON, J. (1988) Measuring Economic Losses Due to Sediment Pollution: logging versus tourism and fisheries. East-West Center. Honolulu, Hawaii, USA.

HOUGHTON, K. and MENDELSOHN, R. (1997) An Economic Analysis of Multiple-use Forestry in Nepal. Ambio Vol. 25 No. 3 pp. 156-159.

HOWARD, P. (1995) The Economics of Protected Areas in Uganda: Costs, Benefits, and Policy Issues. A dissertation for the University of Edinburgh.

IUCN. (1994) Guidelines for Protected Area Management Categories. IUCN, Gland, Switzerland and Cambridge, UK.

KUMARI, K. (1995) An Environmental and Economic Assessment of Forest Management Options: a case study in Malaysia. The World Bank, Washington DC, USA.

LAL, P. (1990) Conservation or Conversion of Mangroves in Fiji. East-West Center. Honolulu, Hawaii, USA.

LAL, P. (1990) Ecological Economic Analysis of Mangrove Conservation; a case study from Fiji. In Mangrove Ecosystems Occasional Papers No. 6. UNDP/ UNESCO. New Delhi, India.

LINDBERG, K. and ENRIQUEZ J. (1994) An Analysis of Ecotourism's Economic Contribution to Conservation and Development in Belize. Vol. 1, Summary Report. Prepared for the World Wildlife Fund, US. 
MARSH, J. (ed.) (1992) Resources and Environment in Asia's Marine Sector. Taylor and Francis. New York, USA.

MCNEELY, J. (1997) Sustainable Finance for Protected Areas. Presented to Protected Areas in the 21st Century: From Islands to Networks. 24-28 November. Albany, Western Australia.

MCNEELY, J. (1997) Tourism and Biodiversity: A natural partnership. Presented to the Netherlands Tourism Meeting. 19-20 March. Amsterdam, Netherlands.

MELNYK, M. and BELL, N. (1996) The Direct Use Values of Tropical Moist Forest Foods: The Houttuja Amerindians of Venezuela. Ambio Vol. 25 No. 7.

MUNASINGHE, M. and MCNEELY, J. (1994) Protected Area Economic Policy. International Bank for Reconstruction and Development, Washington DC, USA.

NATIONAL PARKS SERVICE. The Money Generation Model 1995-1996. Office of Social Science, Denver, Colorado.

NORTON-GRIFFITHS, M. (1994) Biodiversity Conservation in Kenya. Dissertation submitted to University College London, UK.

PAGIOLA, S. (1996) Republic of Croatia Coastal Forest Reconstruction and Protection Project. Annex 1 Economic Analysis. The World Bank, Washington DC, USA.

PEARCE, D., MARKANDYA, A. and BABIER, E. (1989) Blueprint for a Green Economy. Earthscan, London.

PEARCE, D. and MORAN, D. (1994) The Economic Value of Biodiversity. Earthscan, London.

PEARCE, D. and TURNER, R.K. (1990) Economics of Natural Resources and the Environment. John Hopkins Press, Maryland.

PENDLETON, L. (1993) Adding It All Up: The economic valuation of a tropical marine park. Presented at Environmental Economics and Policy Analysis Workshop. HIID, USA.

READ-STURGESS AND ASSOCIATES. (1994) The Economic Significance of the Grampians National Park. Department of Conservation and Natural Resources, Melbourne, Australia.

ROSE, V. (1996) What's a Park Worth? National Parks and Conservation Association. Available on the Internet at $<$ http://www.npca.org $>$.

SHYAMSUNDAR, P. and KRAMER R. (1997) Biodiversity Conservation-At What Cost? A study of households in the vicinity of Madagascar's Mantadia National Protected area. Ambio Vol. 26 No. 3 pp. 180-184. 
STUART-HILL, G. and GROSSMAN, D. (1993) Protected areas, Profits and Professionalism: lion returning to Pilanesberg. African Wildlife Vol. 47 No. 5 pp 267-270.

t'SAS-ROLFES, M. (1997) The Kruger National Park: South African Heritage or Wasted Asset?

ULPH, A. and REYNOLDS I. (1981) An Economic Evaluation of National Parks. Center for Resource and Environmental Studies, Australian National University, Canberra.

UNESCO. (1997) Operational Guidelines for the Implementation of the World Heritage Convention. Intergovernmental Committee for the Protection of the World Cultural and Natural Heritage.

VORHIES, D. and VORHIES, F. (1993) Introducing Lion into Pilanesberg: an economic assessment. Eco Plus (Pty) Ltd. Johannesburg, South Africa.

WELLS, M. P. (1997) Economic Perspectives on Nature Tourism, Conservation and Development. Environment Department Working Paper No. 55. The World Bank, Washington DC, USA. 
IUCN Communications Division

Rue Mauverney 28

CH-1196Gland, Switzerland

Tel: + + 41 22-999 0001

Fax: ++ $4122-9990010$

E-mail: mail@hq.iucn.ch
IUCN Publications Services Unit 219c Huntingdon Road Cambridge, CB3 ODL, UK Tel: ++44 1223-277894 Fax: + + 44 1223-277175 E-mail: iucn-psu-@wcmc.org.uk 